\title{
Transitions to Adulthood in the Context of AI DS in South Africa: Report of Wave I
}

\section{March 2001}

\author{
Naomi Rutenberg \\ Cathrien Kehus-Alons \\ Lisanne Brown \\ Kate Macintyre \\ Anthea Dallimore \\ Carol Kaufman
}

\section{Hqrizons}

12 Population Council

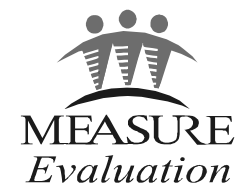




\section{Acknowledgements}

The Transitions to Adulthood in the Context of AIDS in South Africa is a research project conducted by the School of Development Studies at the University of Natal, Durban; the Horizons Project; the Policy Research Division of the Population Council; Focus on Young Adults; and MEASURE/Evaluation Project of Tulane University in New Orleans. The Transitions to Adulthood study team members are:

\author{
University of Natal, Durban \\ Julian May \\ Ntsiki Manzini \\ Population Council \\ Carol Kaufman (now with University of Colorado \\ Health Sciences Center) \\ Naomi Rutenberg
}

\author{
$\underline{\text { Tulane University }}$ \\ Lisanne Brown \\ Cathrien Kehus-Alons \\ Bob Magnani \\ Kate Macintyre \\ DRA-development \\ Stavrou Stavros \\ Anthea Dallimore
}

The Transitions to Adulthood study team would like to thank Ntsiki Manzini, University of Natal, and Thom Eisele, Tulane University, for assistance with the preparation of this report; Francie Lund, University of Natal, Durban, Debbie Budlender, CASE, and Linda Richter, University of Natal, Pietermaritzburg, for their review of earlier drafts and guidance in the interpretation of results; and Simon Baker, Horizons/Program for Applied Technology in Health, and Ann McCauley, Horizons/International Center for Research on Women, who read and commented on the final draft.

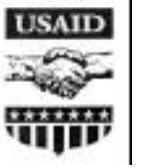

This publication is made possible through support provided by the U.S. Agency for International Development through the Horizons Project (under the terms of co-operative agreement No. HRN-A-00-97-00012-00), the FOCUS on Young Adults Project (co-operative agreement No. CCP-3-73-A00-6002-00), the MEASURE/Evaluation Project (co-operative agreement HRN-A00-97-00018-00), and by a Rockefeller Foundation grant to the Policy Research Division of the Population Council. The opinions expressed herein are those of the authors and do not necessarily reflect the views of the U.S. Agency for International Development or the Rockefeller Foundation.

Published in March 2001.

\section{(2 Population Council}

The Population Council is an international, nonprofit, nongovernmental equitable, and sustainable balance between people and resources. The Council conducts biomedical, social science, and public health research and helps build research capacities in developing countries. Established in 1952, the Council is governed by an international board of trustees. Its New York headquarters supports a global network of regional and country offices.

Copyright (C) 2001 The Population Council Inc. 


\section{Executive Summary}

Transitions to Adulthood in the Context of AIDS in South Africa is a prospective study of reproductive behavior and sexual health of adolescents in South Africa as well as their education and employment experiences, family and environmental conditions, and other factors in their lives that may influence their sexual behavior and choices. The Transitions study is designed to make an important contribution to our understanding of how the national Life Skills Programme works and its effectiveness in changing the behavior of students. The final goal of the Transitions study is to contribute to designing and refining policies and programs that will improve opportunities and capacities of adolescents and may contribute to changing behaviors and choices.

The study design includes two rounds of data collection from adolescents (ages 14-22), data on their households and communities, and an exploration of some of the principal results from the survey data based on focus groups and other qualitative approaches. Additional data are collected at baseline and follow-up from all schools in the study area regarding the teaching of the Life Skills Programme in those schools.

This report is designed to inform educators, policymakers, and the public in South Africa and beyond of the initial findings of the study. We focus in this report on describing the context of adolescence including education and employment experience, reproductive and sexual health knowledge and events and the coverage of the school-based Life Skills Programme. This detailed description is based on the first round of data collection from the Transitions study. In subsequent analyses, we will explore the interrelationships among study variables and, following a second round of data collection with the same respondents, evaluate the impact of the Life Skills Programme. 



\section{Table of Contents}

Introduction 1

Objectives 1

Study setting $\quad 5$

$\begin{array}{ll}\text { Methodology } & 6\end{array}$

Socioeconomic and Demographic Characteristics of

Communities, Households, and Individuals 9

$\begin{array}{lr}\text { Community characteristics } & 9\end{array}$

$\begin{array}{ll}\text { Household characteristics } & 10\end{array}$

$\begin{array}{ll}\text { Individual characteristics } & 13\end{array}$

Family and Community Context 16

Connectedness to family and friends 16

Connectedness to community 20

Membership in neighborhood/community associations 23

School Context and Life Skills Programme 26

School environment 26

Connectedness to school 27

Exposure to Life Skills $\quad 30$

Risk Taking and Health-seeking Knowledge and Behavior 35

HIV knowledge, stigma, and perception of risk and testing 35

Knowledge of other sexually transmitted infections 37

$\begin{array}{ll}\text { Sexual experience and relationships } & 37\end{array}$

Pregnancy preferences and knowledge of pregnancy risks 38

$\begin{array}{ll}\text { Condoms } & 40\end{array}$ 
Family planning information and use

Alcohol and drug use

Sexual abuse and violence

Transitions To Adulthood

Sexual health outcomes $\quad 46$

Education and work experience $\quad 51$

Conclusions

References 


\section{Introduction}

\section{Objectives}

Societal transformations in South Africa and elsewhere have contributed to a lengthening of the period between puberty and marriage, particularly for girls; an increase in the number and nature of contacts by adolescents outside the family and immediate community; and greater opportunities and potential for youth to extend their education and skills development (Bongaarts and Cohen 1998; Mensch, Bruce, and Greene 1998; Caldwell et al. 1998). But they have at the same time increased the exposure of adolescents to premarital and unsanctioned sexual activity with all its attendant health and social consequences (Blanc and Way 1998; Zabin and Kiragu 1998). What happens during the adolescent years sets the boundaries for what is possible later in life. Thus the impact of society and social programmes on youth's sexual behavior, the education and work opportunities available to youth, and the quality of the transitional period between childhood and adulthood are the main focus of this study. ${ }^{1}$

Opportunities for South African youth in the near future are greatly threatened by the AIDS epidemic. Unprotected sexual intercourse among youth is fueling that epidemic. South Africa has one of the highest HIV infection rates in the world, and the prevalence of the disease among South African youth is particularly alarming. In 1999, the (low) estimate of HIV prevalence among young women age 15-24 was 23 percent; the comparable figure for young men was 8 percent (UNAIDS 2000). Moreover, while South Africa's total fertility level is estimated to be one of the lowest in sub-Saharan Africa, less than 3.3 nationally and declining (Central Statistical Service 1997), adolescent childbearing levels do not appear to be changing. In 1993, 43 percent of 19-year-old black girls had given birth at least once (Mazur 1995), a level approximating that experienced by their mothers and grandmothers before them (Preston-Whyte 1990). However, many women who start childbearing as adolescents have few children later in life. The reproductive behavior of today's youth is not only a concern because of the social, economic, and personal costs associated with early childbearing, but also because it will shape the trajectory and impact of the AIDS epidemic for future generations.

A recent review of the evidence on sexual risk taking among adolescents in the United States concluded that such behaviors are affected by a large number of risk and protective factors including their partners, friends, families, and communities (Kirby 1997). These factors include not just sexual beliefs and skills but a broad array of social and economic factors, including poverty and social disorganization, that condition youth's choices, actions, and outcomes. The research findings on the effectiveness of programmes or interventions aimed at reducing the prevalence of adverse adolescent reproductive health outcomes in the U.S. strongly suggest that programmes that attempt to influence the context in which youth live in addition to addressing reproductive health

\footnotetext{
${ }^{1}$ The terms youth, adolescent, boy, and girl are used interchangeably throughout this report. The focus of our research is on young people between the ages of 14 and 22 .
} 


\section{Hgrizons}

needs tend to be more effective than those that focus more narrowly on reproductive health knowledge and/or access to contraceptive/reproductive health services.

Very little research on adolescent reproductive behavior exists in South Africa due to academic isolation and the politicization of population and family planning issues under the former regime (Kaufman 1997). Studies that exist are often narrow in their scope, containing either an HIV/AIDS or an early childbearing focus; few have integrated conceptually or methodologically the issues surrounding early sexual activity and exposure to HIV for youth. The studies centrally concerned with HIV/AIDS tend to stress questions of knowledge of transmission, condom use, and patterns of sexual activity; studies on early childbearing tend to emphasize cultural determinants, such as the value of children, or the political forces that contributed to early childbearing and unstable unions. One of the few studies that has considered both HIV and sexual activity or early childbearing does not herald good news. Varga (1997) found that for her sample of youth, AIDS is not a significant factor in sexual decision-making.

While increasingly more attention is paid to the risks of HIV/AIDS to youth, the base of research providing an integrated approach to the lives of young South Africans is very thin. Few studies of South African adolescents have systematically examined the links among school, work, and reproductive behavior, nor have they looked at how programmes targeted at youth condition those relationships. Most studies lack a systematic assessment of community context. The programme climate is changing rapidly in South Africa, and prior studies do not examine the variety of reproductive health and family planning programmes, including abortion; whether the multiplicity of programmes and educational information work in unison or opposition; or how youth obtain or act on information.

A key strategy in the state's response to the HIV/AIDS epidemic is a national Life Skills Programme initially in secondary schools and now expanding to primary schools. The effectiveness of the Life Skills Programme - and the ways in which life skills training combines with other resources in families or communities to influence reproductive and sexual health outcomes-is of special concern given its prominent role in the government's response to HIV/AIDS.

In November 1995 the Department of Health (DoH) and the Department of Education (DoE) formed the National Coordinating Committee for Life Skills and HIV/AIDS. The committee gave highest priority to establishing a Life Skills and HIV/AIDS education course in secondary schools

(grades 8-12), with the expectation that the course, implemented in each province by the provincial DoE according to its own plan, would be in place nationwide by January 1998. The goal of Life Skills and HIV/AIDS Education: Learning Programme for Grades 8-12 is to increase knowledge, develop skills, promote positive and responsible attitudes, and provide motivational supports (South Africa Department of Health and South Africa Department of Education 1997/98). Expected outcomes are that at the end of the programme students will be able to:

- Demonstrate a clear and accurate understanding of sex, sexuality, gender, and sexually transmitted diseases.

- Critically identify ways in which HIV/STDs can and cannot be transmitted.

- Identify and evaluate the effectiveness of HIV/STD prevention methods. 
- Identify, access, and mobilize sources of assistance within a community.

- Critically evaluate reasons for delaying sexual intercourse or practicing abstinence.

- Respond assertively to pressures for sexual intercourse.

- Critically evaluate reasons and methods for having protected sex when/if sexually active.

- Respond assertively to pressures for unprotected sex.

- Accept, cope, and live positively with the knowledge of being HIV-positive.

- Show compassion, empathy, and solidarity toward persons with HIV/AIDS and those affected.

- Recognize the need to provide basic care for people with AIDS in the family and community and those affected.

- Understand the grieving process and cope with loss.

The National Project Committee oversaw the development of the Life Skills curriculum and developed guidelines for implementation. In South Africa, however, each province designs and implements its own programmes assisted by the national directorates (including the National AIDS Programme), which provide policy and other resources. Thus the DoE in each province made its own plans to implement a Life Skills Programme.

In 1998, both the Planned Parenthood Association of South Africa (PPASA) and Community Agency for Social Enquiry (CASE) evaluated the effect of the teacher training and subsequent programme implementation. According to a DoH review of both studies, they identified several needs, including improved and additional training, training updates, and further orientation and motivational workshops for officials at middle management and representatives of school governing bodies. The national $\mathrm{DoH} / \mathrm{DoE}$ response to the evaluation included a plan to provide assistance to each province to improve and evaluate the programme in 2000.

Although the Life Skills Programme is a key strategy in the state's response to the epidemic, we know little about the programme's effectiveness, or the way in which Life Skills training combines with other resources in families or communities to influence reproductive outcomes. This is a prospective study of reproductive behavior and sexual health of adolescents in South Africa as well as their education and employment experiences, family and environmental conditions, and other factors in their lives that may influence their sexual behavior and choices. The Transitions study makes an important contribution to our understanding of how the programme works and its effectiveness in changing the behavior of students.

The principal outcomes of interest for our study are sexual health outcomes and education and work opportunities. Sexual health outcomes include experience of a sexually transmitted disease, unwanted and/or unsafe pregnancy, and abortion. Youth educational and work opportunities include the pace and progress of an adolescent through school, the types of work opportunities available (which depend on the availability of employment in the formal and informal sector), educational opportunities, and experience of childbearing. There may, of course, be strong gender differentials within these various opportunities.

We believe that the sexual health and youth opportunity outcomes are highly interconnected. For example, boys who find jobs in the formal sector are perceived to be more responsible partners in 


\section{Hgrizons}

family planning, and anecdotal evidence suggests they may also be more likely to use a condom. Boys who work are also thought to be more likely to acknowledge paternity and to continue supporting a child even if there is no marriage. For girls, acquiring and keeping a job may correspond with high motivation to use family planning, to effectively negotiate with partners about sex and condom use, and to delay marriage and childbearing. The panel design of the study and subsequent analysis following the Wave II data collection will allow for a quantification of these associations, which are often lost or unmeasurable with cross-sectional data.

The Transitions study has the following primary objectives:

- To investigate the impact of Life Skills curricula and other programmes on addressing adolescent understanding of STDs/HIV transmission and personal risks, attitudes toward persons living with AIDS, and risk-taking and health-seeking behavior, especially those behaviors associated with the spread of STDs/HIV.

- To document patterns and trends - and the relationships among them over the life course of the adolescent-in the key events during an adolescent's transition to adulthood, including sexual initiation and subsequent sexual relationships, experience of sexually transmitted diseases, risktaking behaviors including unprotected sex, school leaving, work, pregnancy, marriage, and first and subsequent births.

- To advance knowledge about the key external factors affecting the incidence and timing of these events as well as the overall quality of adolescence in terms of capacity development. External factors include education and the quality of schooling experiences, types of work opportunities, violence in communities or in relationships, peer relationships, youth-oriented community programmes or organizations, and the reproductive health environment.

The final goal of the Transitions study is to contribute to designing and refining policies and programmes that will improve opportunities and capacities of adolescents and may contribute to changing behaviors and choices. Specific outcomes of the study include:

- A description of the incidence and timing of key events during an adolescent's transition to adulthood, including sexual initiation and subsequent sexual relationships, risk-taking behaviors including unprotected sex, school leaving, work, pregnancy, marriage, and first and subsequent births.

- A description of the coverage of Life Skills curricula in schools and estimates of the proportions of adolescents who have been exposed to Life Skills education as well as community-based programmes.

- An improved understanding of how schooling and work opportunities and household characteristics impede or encourage sexual activity, contraceptive use, and timing of childbearing over the life course of young adulthood.

- An evaluation of the impact of the Life Skills Programme on changing levels of knowledge about HIV/AIDS and reducing adolescent behaviors that put them at risk of HIV.

This report is designed to inform educators, policymakers, and the public in South Africa and beyond of the initial findings of the study. We focus in this report on the first two study outcomes listed above: describing the context of adolescence, including education and employment 
experience, reproductive and sexual health knowledge and events; and the coverage of the schoolbased Life Skills Programme. This detailed description is based on the first round of data collection from the Transitions study. ${ }^{2}$ In subsequent analyses, we will explore the relationships between study variables, and following a second round of data collection with the same respondents, evaluate the impact of the Life Skills Programme.

The Transitions study is conducted by the School of Population and Poverty Studies at the University of Natal, Durban, the Horizons Project, the Policy Research Division of the Population Council, and Focus on Young Adults (FOCUS), and the MEASURE/Evaluation Project of Tulane University. The study is funded by USAID and the Rockefeller Foundation. Field work for the first round of data collection was carried out by an independent South African research organization, DRA-development, and data entry and cleaning were done by Policy and Praxis, an independent data management organization.

The survey data are complemented by data on communities (collected in May and June 2000) and an exploration of some of the principal results from the survey data based on focus groups and other qualitative approaches (carried out in August and September 2000).

\section{Study setting}

KwaZulu-Natal (KZN) was selected as the site for this study for three reasons. First, the province has high rates of HIV infection-some of the highest in the country-and the urgency of the problem to youth and policy and programmes is great. Second, experienced and interested researchers (from the School of Development Studies at the University of Natal) were available to collaborate on the research. Third, the provincial experience with the Life Skills Programme is fairly typical in that the programme has been implemented unevenly in secondary schools.

KwaZulu-Natal is situated on the east coast along the Indian Ocean. With a population of 8.4 million KZN is South Africa's largest province, containing one-fifth of the country's population. The population is about 45 percent urban and includes Durban, the largest port and third largest city in the country. About 25 percent of the country's black population resides in the province. Africans, primarily Zulu-speaking, make up about 76 percent of the population. Indians comprise 14 percent of the population, 7 percent are White, and 3 percent are Coloured. During the mid1980s and again in the early 1990s there was substantial political unrest and violence in KwaZuluNatal and, as a result, the first democratic local elections were not held until 1996, a year later than the rest of the country. While KwaZulu-Natal should not be considered a typical or representative province, many of the underlying social and economic conditions are similar to those found in other provinces in which a substantial proportion of the population resides in the former homeland areas.

\footnotetext{
2 This report does not include statistical tests of group differences or associations. These analyses will be presented in a series of papers planned as part of the overall study analysis plan.
} 


\section{Hgrizons}

KZN has the highest level of HIV infection in the country; HIV prevalence among antenatal clinic attendees was an estimated 33 percent in 1998 (South Africa Department of Health 1999). The high prevalence and rapid rise in its level have been attributed to widespread migrant labor in the province and its association with multiple partners; lack of condom use mainly because of the device's association with distrust between partners and a lack of cleanliness; high value placed on multiple partnerships by men; high levels of poverty in the province; and poor health care services (Whiteside 1999).

A situation analysis of the teacher-training component of the Life Skills Programmes in the provinces in 1996 documented that some provinces already had (to a lesser or greater degree) Life Skills or HIV/AIDS education programmes implemented in schools, while others had yet to begin. The Provincial Coordinating committees were given the option to enrich and fast track their own initiatives by submitting a business plan. KwaZulu-Natal already had an ongoing Life Skills Programme and decided to adjust it to meet the aims of the national programme. The province prepared a business plan for teacher training, which was approved by the Department of Health, which allocated one million Rand (the amount allotted to each of four provinces who prepared business plans) to implement the plan. DoH in KwaZulu-Natal contracted with the Pietermaritzburg AIDS Action Group to administer the budget according to the approved business plan. Training commenced in August 1997, and 1,000 teachers (of the possible 1,200) were trained by the conclusion of the project in 1998 (Markham 1998).

An evaluation of the teachers' training in Life Skills instruction, undertaken in 1998, indicated that the programme on Life Skills in the province had undergone a number of setbacks, including delays in government funding, poor development of materials, and untrained trainers (Markham 1998). While some progress since that time has occurred, no further evaluations have been undertaken. Anecdotal evidence suggests that Life Skills Programmes in schools remain uneven in quality and comprehensiveness both across and within schools.

\section{Methods}

Two administrative areas within the province-the Durban Metropolitan and Mtunzini Magisterial Districts-were purposively selected within KwaZulu-Natal, and their combined populations provide the universe for this study. These administrative areas were selected to ensure a variety of urban, transitional and rural regions within the province. The urban group (77 percent of the sample) used in this report refers to all respondents taken from the Durban Metro sample as well as those living in urban areas within the Mtunzini Magisterial District. The rural group (23 percent) refers to all respondents from the rural areas of Mtunzini.

The study used a modified multi-stage cluster sample approach. The first stage required the random selection of 120 enumeration areas (EAs) from a sampling frame of all EAs in the two districts. At the second stage, field supervisors divided EAs into approximately equal segments of a predetermined size (based on an estimate for the average number of adolescents we could expect to 


\section{Transitions to Adulthood}

find per household derived from census data). ${ }^{3}$ The study team then selected one segment randomly, and interviewers tried (in up to three visits) to find all households within that segment and to interview every young person between the ages of 14 and 22 reported to live in those households. The data collection teams were composed of men and women in proportion to the race and gender distribution in the sample, and nearly all interviews were conducted by same race and sex interviewers and by interviewers speaking the respondent's preferred language.

Data collection teams administered a household questionnaire to each household that contained one or more adolescents between the ages of 14 and 22. The household questionnaire included questions about the household members, living conditions, economic shocks, expenditure, government assistance, and discussions about HIV in the household. The first wave of data collection included structured interviews with 2,007 households that had adolescent members between the ages of 14 and 22 in 118 of the 120 selected segments. Two EAs in rural areas were excluded during data collection due to insecurity and lack of permission to enter the area. Field supervisors instructed interviewers to try to find the responsible adult in the household and told them not to speak with anyone under the age of 16 . Interviewers questioned the head of the household or her/his spouse in 62 percent of the households. Children of the head of the household responded in one-quarter of the interviews. Interviewers conducted the remaining interviews mainly with other relatives. Females responded predominantly to the household questionnaire (72 percent).

In these 2,007 households, interviewers identified 3,770 adolescents between the ages of 14 and 22 and completed individual interviews with 3,096 respondents. This interview covered the background characteristics of the respondents, education history, work experience, a diary of their activities in the previous 24 hours, exposure to the school-based Life Skills Programme, sexual relationships, contraceptive and condom knowledge, attitudes and use, connectedness to school, family and community, alcohol and drug use, and reproductive history.

Interviewers conducted the interviews during a six-week period from 16 September to 7 November 1999. Overall, interviewers completed interviews with 82.2 percent of the adolescents identified in the selected households. However, response rates varied by population group. Interviewers successfully completed interviews with 90.9 percent of eligible adolescents among Africans in rural areas, 83.6 percent among Africans in urban areas, 69.6 percent among Asians, and 67.5 percent among Whites (the latter two groups were only selected in urban areas). These differences arise from the different patterns of activities among population groups, which keep some youth more than others away from home. This analysis of the individual data is based on weighted data, to control for clustering and non-response.

Community characteristics were assessed in 113 of the $118 \mathrm{EAs}^{4}$ selected during the sampling process for the survey of adolescents. Two complementary methods were used. First, interviewers

\footnotetext{
3 This segmentation procedure was used to avoid the cost of creating a list of all households prior to survey work (Turner et al. 1996).

${ }^{4}$ Five of the 118 EAs selected were excluded because of insecurity in the area or lack of permission of local authorities to enter the area.
} 


\section{Hgrizons}

gathered data through observation, assessing the presence and quality of physical infrastructures, community maintenance, and general observable cleanliness of those structures. They also observed transportation networks, public telecommunications, and other services. Second, interviewers compiled data using a street intercept module, where interviewers conducted interviews with people living in the community. Interviewers recruited respondents at several central locations in the community, such as in shopping centers, bus stops, or along busy streets. Field supervisors instructed interviewers to talk with 40 respondents living in the EA, who were evenly divided by sex and by age group: 14 to 30 years old and 31 and older. This was achieved in most EAs. Interviewers asked questions concerning the perceived levels of crime and safety in the community. Also, interviewers assessed the use of different means of transport, participation in community activities, and perception of HIV risk and attitudes toward people living with AIDS.

For our purposes, a community is defined by the administrative boundaries of the EA. For the street intercept interviews, interviewers described these boundaries to the respondents to establish their eligibility to participate and defined for them the area to which questions referred. Data from the intercept surveys indicate that the collective perceptions of the individuals interviewed and observation data are reflective of the individual researcher/data collector; these views may be open to varied interpretations.

Of the 113 communities, 16 were in the rural area of Mtunzini Magisterial District and the population was all African. The other 97 communities were in Durban Metro and urban areas of Mtunzini Magisterial District. Sixty-one were largely African, fourteen were largely Asian, and two had a Coloured population. Of the remaining 20 communities, 7 were White, while 13 communities had a mixed population. ${ }^{5}$ In our analysis the Coloured EAs were combined with the mixed areas.

\footnotetext{
${ }^{5}$ Ethnicity of the community was based on the ethnicity of the respondents in the street intercept module and of the adolescents of that community who participated in the adolescent survey. EAs in which there was no clear majority are defined as "mixed."
} 


\section{Socioeconomic and Demographic Characteristics of Households and I ndividuals}

This chapter presents information on social and economic characteristics of communities, households, and individuals visited and interviewed in the Transitions study. These descriptive data offer a context for the interpretation of the data on sexual health and education and work experience, as well as provide an indication of the representativeness of the sample.

\section{Community characteristics}

The availability of physical structures within a community affects opportunities for recreation and other kinds of informal and formal gatherings, which contribute to community identity and cohesion. Other aspects of the physical environment affect security and sanitation. A disorderly environment may be a signal that there are few rules and no one cares; such an environment is conducive to antisocial behaviors such as truancy and drug use, which are also associated with high-risk sexual behavior (Cohen et al. 2000)

Several measures of neighborhood conditions are presented in Table 1. One desirable feature is the availability of open spaces and/or a park for recreation and schools, which offer a place for people from a community to come together. Thirteen percent of the urban African communities do not have any type of open space. Parks ${ }^{6}$ are more often found in the mixed and White communities. Fewer than half of the communities had a school within the boundaries of the EA, suggesting that students must commute to other parts of their community or city for the school day.

We also measured disorder by the extent of abandoned buildings, the availability of street lighting, the presence of or proximity to a squatter settlement, and the presence of rubbish. Abandoned buildings are most common in African communities and least common in Asian areas. Street lighting is present throughout the Asian and Coloured communities and most of the White and mixed communities (89 and 92 percent of the streets on average, respectively). Only half of the streets in the urban African communities are lit at night. Several of the communities are adjacent to or have squatter settlements within them. This is the case for 61 percent of the urban and 19 percent of the rural African communities. Twenty-one percent of the Asian and seven percent of the mixed communities are adjacent to a squatter settlement. When looking at cleanliness of the community, the White and rural African communities are the cleanest and the Asian and urban African communities the least clean.

\footnotetext{
${ }^{6}$ Communities were considered to have a park if it was properly maintained, i.e. it had mowed grass and any structures were functional.
} 
Table 1 Percentage of communities with absence or presence of certain infrastructures

\begin{tabular}{|c|c|c|c|c|c|c|}
\hline & $\begin{array}{c}\text { African } \\
\text { rural } \\
(\mathrm{n}=16) \\
\end{array}$ & $\begin{array}{c}\text { African } \\
\text { urban } \\
(\mathrm{n}=61) \\
\end{array}$ & $\begin{array}{c}\text { Asian } \\
(n=14)\end{array}$ & $\begin{array}{l}\text { White } \\
(n=7)\end{array}$ & $\begin{array}{l}\text { Mixed }^{*} \\
(n=15)\end{array}$ & $\begin{array}{c}\text { Total } \\
(n=113)\end{array}$ \\
\hline \multicolumn{7}{|l|}{ Presence of a park } \\
\hline no parks present & 100 & 87 & 71 & 43 & 40 & 78 \\
\hline park without lights & 0 & 5 & 0 & 0 & 0 & 3 \\
\hline park with lights from the street & 0 & 7 & 29 & 43 & 40 & 15 \\
\hline park with lights in the park & 0 & 2 & 0 & 14 & 20 & 4 \\
\hline No open space in the community & 0 & 13 & 0 & 0 & 0 & 7 \\
\hline Has a school in the community & 50 & 41 & 57 & 29 & 67 & 47 \\
\hline Presence of abandoned lots & 31 & 61 & 57 & 14 & 47 & 51 \\
\hline $\begin{array}{l}\text { Presence of abandoned/burnt } \\
\text { buildings }\end{array}$ & 25 & 21 & 7 & 14 & 20 & 20 \\
\hline Has a squatter settlement in/next to it & 19 & 61 & 21 & 0 & 7 & 39 \\
\hline $\begin{array}{l}\text { Percentage of streets with working } \\
\text { lights }\end{array}$ & 5 & 52 & 100 & 89 & 93 & 59 \\
\hline Presence of rubbish (scale $0-4)^{\star *}$ & 0.2 & 1.5 & 1.6 & 0.0 & 0.9 & 1.2 \\
\hline \multicolumn{7}{|l|}{ * Includes Coloured. } \\
\hline \multicolumn{7}{|c|}{$\begin{array}{l}\text { ** This was assessed by looking at the presence of rubbish on the streets, outside shops, bars and kiosks, outside the } \\
\text { houses, and sewage on the roads. An index on a scale of } 0-4 \text { was created by giving a point for each site where } \\
\text { rubbish was present. }\end{array}$} \\
\hline
\end{tabular}

\section{Household characteristics}

The distribution of the 2,007 households interviewed by population group is presented in Table 2 . Of the households interviewers questioned, 72 percent are located in EAs with a predominantly African population, 19 percent in EAs with a predominantly Asian population, 6 percent in EAs populated mainly by Whites, and the remaining 3 percent in EAs with a Coloured population. The majority ( 84 percent) of the households are located in the Durban and Mtunzini urban areas. The 16 percent of the households located in the rural areas of Mtunzini are all African families.

The average household size was computed based on the reported number of people who usually live in the household; this may include non-family members. As seen in Table 2, households contain an average of 6.2 people. Rural African households are the largest, with an average of 8.4 people in the household. White households are the smallest and consist of only 4.2 people. Average household size among the other urban groups ranges from 5.1 for Asians to 6.1 for Africans.

In slightly more than one-third of the households, the respondent identified a female household member as the head of the household. This percentage is more than twice as high among African households as among households in the other population groups. In 35 percent of rural African households and 48 percent of urban African households, the person identified as the head was female; among other population groups, 20 percent or fewer of the households are female-headed. 


\begin{tabular}{lccc} 
Table 2 Household characteristics $\mathbf{~} \mathbf{n = 2 , 0 0 7}$ households) \\
\hline $\begin{array}{c}\text { Main population } \\
\text { group of EA }\end{array}$ & $\begin{array}{c}\text { Distribution } \\
\text { in sample } \\
\%\end{array}$ & $\begin{array}{c}\text { Average size } \\
\text { of household } \\
\text { mean }\end{array}$ & $\begin{array}{c}\text { Female- headed } \\
\text { households } \\
\%\end{array}$ \\
\hline African rural & 56 & 8.4 & 35 \\
African urban & 16 & 6.1 & 48 \\
Asian & 19 & 5.1 & 20 \\
White & 6 & 4.2 & 19 \\
Coloured & 3 & 5.4 & 17 \\
All & $\mathbf{1 0 0}$ & $\mathbf{6 . 2}$ & $\mathbf{3 8}$ \\
&
\end{tabular}

The socioeconomic status of households was assessed by housing conditions (type of house and presence of electrical power and/or sanitation) and yearly household expenditure on food and nonfood items. Table 3 presents the type of house and the presence of electricity and/or sanitation for the households in the sample, by population group and place of residence. Almost all Coloured, Asian, and White households live in permanent brick houses with a connection to electricity, internally piped water, and sewage. The housing conditions of many Africans are much more basic, especially in the rural areas, with many lacking electricity or internally piped water. While somewhat more than one-half ( 53 percent) of the urban African families live in permanent houses, 21 percent live in homes built of traditional material of mud and thatch, 20 percent live in what was considered a permanent shack, and the remaining 6 percent live in temporary shacks. Only 29 percent of rural African families live in permanent houses, 42 percent live in traditionally built houses, and 21 percent in permanent shacks.

Only 79 percent of the urban African households have electricity compared to virtually all households of the other urban population groups. Less than half (44 percent) of African households in the rural areas have electricity. A similar difference between the Africans and the other population groups is evident with regard to water and sanitation. Among urban African families, just over half draw water from a yard tap or public tap, and 50 percent of households have flush toilets; the vast majority of those without flush toilets rely on latrine-style toilets. Piped water and flush toilets are virtually nonexistent in rural African households. Rural residents rely on naturally flowing water (32 percent), boreholes (31 percent), and yard and public taps ( 25 percent) for water, and most (79 percent) have a latrine. 
Table 3 Percent of households by type of house, electricity, water, and sanitation by population group $(n=2,007)$

\begin{tabular}{|c|c|c|c|c|c|c|c|}
\hline \multirow[b]{2}{*}{$\begin{array}{l}\text { Population } \\
\text { group }\end{array}$} & \multicolumn{4}{|c|}{ Type of house } & \multicolumn{3}{|c|}{ Electricity/water/sanitation } \\
\hline & $\begin{array}{c}\text { Traditional } \\
\text { materials } \\
\%\end{array}$ & $\begin{array}{c}\text { Temporary } \\
\text { shack } \\
\%\end{array}$ & $\begin{array}{c}\text { Permanent } \\
\text { shack } \\
\%\end{array}$ & $\begin{array}{c}\text { Permanent } \\
\text { house } \\
\%\end{array}$ & $\begin{array}{c}\text { Electricity } \\
\text { present } \\
\%\end{array}$ & $\begin{array}{c}\text { Piped } \\
\text { water } \\
\%\end{array}$ & $\begin{array}{c}\text { Flush } \\
\text { toilet } \\
\%\end{array}$ \\
\hline $\begin{array}{l}\text { African } \\
\text { rural }\end{array}$ & 42 & 8 & 21 & 29 & 44 & 7 & 2 \\
\hline $\begin{array}{c}\text { African } \\
\text { urban }\end{array}$ & 21 & 6 & 20 & 53 & 79 & 79 & 50 \\
\hline Coloured & 0 & 0 & 0 & 100 & 100 & 100 & 100 \\
\hline Asian & 0 & 0 & 1 & 99 & 99 & 100 & 100 \\
\hline White & 0 & 0 & 0 & 100 & 99 & 99 & 100 \\
\hline All & 19 & 5 & 15 & 62 & 79 & 51 & 56 \\
\hline
\end{tabular}

Relative difference in household income was estimated on the basis of data on household expenditures. We asked respondents about individual household expenditures on food and regular non-food items such as rent, electricity, water, phone, and transport during the past month as well as expenditures on infrequent items as clothing, costs for education, furniture, and other durables in the past year. From this information the yearly expenditures of the household on food, and regular and irregular non-food items were calculated. As is often the case with survey data on expenditures, these data should be viewed with caution. First, if interviewers interviewed a person who was not generally responsible for household expenditures, their answers may only be rough estimates. Second, interviewers recorded respondents' answers within ranges, e.g., R1 - R100, R101 - R200, ...R6000+. To calculate average expenses, the upper limit of each category was used and expenses for the last month multiplied by 12 to obtain yearly expenses on food and regular non-food items. As a result yearly expenses in the different categories are only rough estimates. Nonetheless, the estimates in this study are of a similar magnitude to those obtained by the KwaZulu-Natal Income and Expenditure Survey (May and Gayadeen 1999).

Table 4 shows the average household expenditure for each population group and by area of residence. ${ }^{7}$ With this approach, we estimate that African families spend on average approximately 5,800 Rand on food each year. Comparatively, White families spend nearly five times as much on food (27,760 Rand), while Coloured and Asian families both spend about two and a half times as much (15,750 and 13,729 Rand respectively). A similar pattern exists with both regular non-food items and irregular items-White families spend the most and African families by far the least. Total yearly expenditure by African families averages about 14,000 Rand. Coloured and Asian families both spend more than three times this amount (45,744 and 42,611 Rand, respectively), while White families spend more than six times this amount (92,129 Rand). African families spend around 50 percent of their yearly expenditure on food, while Coloured, Asian, and White families

\footnotetext{
${ }^{7}$ Expenditures in 1999 Rand. In September 1999, approximately 6.1 Rand were equivalent to 1 US dollar.
} 
all spend about one-third of their total yearly expenditure on food $(37,35$, and 33 percent, respectively).

\begin{tabular}{|c|c|c|c|c|c|c|}
\hline $\begin{array}{l}\text { Population } \\
\text { group }\end{array}$ & Food & $\begin{array}{l}\text { Non- } \\
\text { food } \\
\text { items }\end{array}$ & $\begin{array}{l}\text { Irregular } \\
\text { items }\end{array}$ & $\begin{array}{c}\text { Total yearly } \\
\text { expenditure } \\
\text { (all items) }\end{array}$ & $\begin{array}{c}\text { Expense } \\
\text { on food } \\
\text { (\% of } \\
\text { total } \\
\text { expense) } \\
\end{array}$ & $\begin{array}{l}\text { Household } \\
\text { per capita } \\
\text { expenditure } \\
\text { (all items) }\end{array}$ \\
\hline African rural & 5,720 & 4,240 & 3,019 & 13,159 & 54 & 1,566 \\
\hline African urban & 5,812 & 6,410 & 2,352 & 14,159 & 48 & 2,321 \\
\hline Coloured & 15,750 & 23,706 & 6,484 & 45,744 & 37 & 8,471 \\
\hline Asian & 13,729 & 22,332 & 6,513 & 42,611 & 35 & 8,355 \\
\hline White & 27,760 & 53,120 & 13,198 & 92,129 & 33 & 21,935 \\
\hline All & 8,929 & 12,536 & 4,101 & 25,463 & 45 & 4,107 \\
\hline
\end{tabular}

In conclusion, urban respondents live in moderate size families with four to six members, while rural families are somewhat larger, with an average of eight members. In urban residences, permanent housing with electricity, piped water, and indoor sanitation are the norm but not universal, with a significant number of African households lacking one or more of these features. Large differences in income, as measured by our proxy of annual expenditure, are found among urban residents. Rural respondents, who were all African, are much less likely to live in permanent housing and have electricity and water service in their home than urban residents. However, rural incomes (as measured by our proxy of annual expenditure) are comparable to the incomes of urban African families.

\section{I ndividual characteristics}

This section and Table 5 present selected demographic characteristics of the respondents who completed the individual questionnaire on Transitions to Adulthood. Fifty-five percent of the respondents were female; the slight underrepresentation of males in our sample reflects the difficulty interviewers had in finding eligible male adolescents at home in the selected households.

One-quarter of respondents are 14-15 years old, half are 16-19 years old, and the remaining quarter are between 20 and 22 years old. For the analyses presented in this report, we have adopted these three age categories (14-15, 16-19, and 20-22) because they capture adolescents at different stages in their transition to adulthood. For example, 14-15-year olds are at the early stages of adolescence; most are beginning secondary school and struggling with adjustments of puberty. By the time youth reach the age of 20, they are establishing new roles as young adults-continuing school, searching for employment, and for many, struggling with the demands of young parenthood. In between these two age groups are those age 16-19. These adolescents are living the consequences 


\section{Hgrizons}

of actions taken in earlier years - for many this will include sexual experiences and other risky behaviors-but many more choices and alternatives are presented to youth in later teen years, choices that may irrevocably shape their adult lives. While no age categories can adequately capture the divergent pathways of adolescence, this grouping provides some discernment of changes over the life course.

The distribution of our sample among population groups is representative of the different population groups in the area. The majority (79 percent) of the sample is African. Durban has a relatively large Asian population compared to the rest of the country and they represent 13 percent of the total sample. Six percent of the respondents are White, while the remaining 1 percent are Coloured.

Over three-quarters (77 percent) of the sample, including all of the Asian, White, and Coloured respondents, live in urban areas of Durban or Mtunzini, while the remaining 23 percent live in rural areas of Mtunzini. Respondents from the Mtunzini rural area are all Africans, which represents 30 percent of the African sample.

The majority of both males and females said they are currently not in a steady relationship (70 percent and 75 percent, respectively). Thirty percent of males said they have a girlfriend, and 23 percent of females said they have a boyfriend. Older adolescents ages 20-22 are more likely to be in a steady relationship, compared to adolescents ages 16-19 and 14-15 (38, 28, and 9 percent, respectively). Less than 1 percent of males and just over 1 percent of females said they are married. Only a few youth reported they are living with someone, widowed, divorced, or separated.

Most respondents are currently enrolled in school (72 percent). Schooling is almost universal among 14-15-year-olds, with 95 percent enrolled. Seventy-five percent of 16-19-year-olds and 43 percent of 20-22-year-olds reported being currently in school. This last group includes a significant number of adolescents older than secondary school age, i.e., older than 18 , still working toward completing secondary school. More than one-quarter (28 percent) of 20-22 year olds are still enrolled in secondary school (and four youth in this age group reported still being enrolled in primary school). Less than 1 percent of both males and females report no formal education.

One-quarter (25 percent) of the respondents said they have worked for cash at some time. More males than females report this type of economic activity (30 and 21 percent, respectively). While over three-quarters (77 percent) of White, two-thirds of Coloured and nearly half (47 percent) of Asian respondents said they have ever worked for cash, only 16 percent of the Africans have done such work (not shown). 


\begin{tabular}{|c|c|c|c|}
\hline $\begin{array}{c}\text { Male }(n=1,402) \\
\text { Female }(n=1,695) \\
\text { Total }(n=3,097)\end{array}$ & $\begin{array}{c}\text { Male } \\
\%\end{array}$ & $\begin{array}{c}\text { Female } \\
\%\end{array}$ & $\begin{array}{l}\text { All } \\
\%\end{array}$ \\
\hline \multicolumn{4}{|l|}{ Age } \\
\hline 14-15 & 24 & 25 & 25 \\
\hline $16-19$ & 52 & 50 & 51 \\
\hline $20-22$ & 24 & 25 & 24 \\
\hline \multicolumn{4}{|l|}{ Population group } \\
\hline African rural & 23 & 23 & 23 \\
\hline African urban & 54 & 57 & 56 \\
\hline Asian & 14 & 13 & 13 \\
\hline White & 7 & 5 & 6 \\
\hline Coloured & 2 & 1 & 2 \\
\hline \multicolumn{4}{|l|}{ Residence } \\
\hline $\begin{array}{l}\text { Durban \& } \\
\text { Mtunzini urban }\end{array}$ & 77 & 77 & 77 \\
\hline Mtunzini rural & 23 & 23 & 23 \\
\hline \multicolumn{4}{|l|}{ Relationship status } \\
\hline $\begin{array}{l}\text { No current steady } \\
\text { relationship }\end{array}$ & 70 & 75 & 73 \\
\hline Steady boy/girlfriend & 30 & 23 & 26 \\
\hline Married (traditional/civil) & 0 & 1 & 1 \\
\hline Living together & 0 & 1 & 0 \\
\hline $\begin{array}{l}\text { Separated/widowed/ } \\
\text { divorced }\end{array}$ & $<1$ & $<1$ & $<1$ \\
\hline \multicolumn{4}{|l|}{ Education } \\
\hline No formal education & $<1$ & $<1$ & $<1$ \\
\hline Currently in school & 77 & 69 & 72 \\
\hline Not in school & 22 & 31 & 28 \\
\hline \multicolumn{4}{|l|}{ Work } \\
\hline Ever worked for cash & 30 & 21 & 25 \\
\hline
\end{tabular}




\section{Family and Community Context}

Several recent studies, including the U.S. National Longitudinal Study of Adolescent Health, have started to shed light on the protective role of youth's connectedness to family, school, and community. These studies suggest that connectedness to family, school, and community is protective for many health behaviors, including smoking, drug use and sex (Brooks-Gunn 1993; Resnick et al. 1997; Jessor, Turbin, and Costa 1998a; Jessor, Turbin, and Costa 1998b; Kirby 1999). The composition and stability, economic wellbeing, and sense of connectedness or cohesion among family and community members influence the effectiveness of Life Skills Programmes as well as the levels of sexual activity among youth. The collection of community data in addition to individual and household level data is important since community level variables may be highly relevant to policymakers (Casterline 1985). The Transitions study included a component to measure connectedness to family, community, and school. The participants' responses to questions on whom they are close to and how safe they feel in their immediate environments are presented in the following sections. In subsequent analysis, we will examine the extent to which these factors influence risk-taking behavior.

We present several dimensions of the social context of the study respondents. One dimension of social context of interest to this study is connectedness to family, school, and community. Connectedness is defined as consistent, stable, positive, emotional relationships with significant others such as parents, friends, teachers, and others who can provide children with important social skills and a sense that the world is safe and secure (Barber 1997). These positive relationships can help to buffer the impact of stressful, negative influences and situations (Resnick et al. 1997).

Another group of contextual variables of importance for this study includes measures of social capital such as perceptions of cohesion and cooperation within the communities and the presence of community groups and activities for youth. A third set of variables of interest are activities and programmes in which youth might become involved, including youth organizations, sport clubs, and church groups. These are additional conduits through which adolescents may receive formal or informal life skills training.

\section{Connectedness to family and friends}

Interviewers asked adolescents to mention one person within their extended family and another person outside of the family to whom they feel closest. The percentage reporting the most common responses are shown in Table 6. Nearly half (47 percent) of the respondents cited their mothers as the person in the family to whom they feel closest. This is true for both males ( 47 percent) and females ( 42 percent). The father is mentioned by only 6 percent of adolescents as the person they feel closest to- 10 percent among males and only 2 percent among females. Siblings appear to play an important role to the adolescents; more than a quarter (27 percent) mentioned a brother or sister as the closest person. Fifteen percent mentioned an aunt/uncle, a grandparent, or some other 
relative. Six percent of the respondents said they feel close to no one in their family. This number ranged from eight percent among urban Africans to zero percent among Coloureds.

When asked to name the person outside the family to whom they feel closest, most adolescents (65 percent) named a friend. Other persons mentioned (much less commonly) were a boyfriend or girlfriend ( 5 percent), teacher ( 2 percent), or neighbor ( 2 percent). A disquietingly high number of adolescents ( 22 percent) stated they could not mention anyone outside the family they feel close to. 
Table 6 Percent of respondents mentioning family and non-family members as the person they feel closest to $(n=3,095)$

\begin{tabular}{|c|c|c|c|c|c|c|c|c|c|c|}
\hline & \multicolumn{5}{|c|}{ Person in the family } & \multicolumn{5}{|c|}{ Person outside the family } \\
\hline & $\begin{array}{c}\text { Mother } \\
\%\end{array}$ & $\begin{array}{c}\text { Father } \\
\%\end{array}$ & $\underset{\%}{\text { Sibling }}$ & $\begin{array}{c}\text { Other } \\
\text { relative } \\
\%\end{array}$ & $\begin{array}{c}\text { No } \\
\text { one } \\
\%\end{array}$ & $\begin{array}{c}\text { Boy/girl } \\
\text { friend } \\
\%\end{array}$ & $\begin{array}{c}\text { Friend } \\
\%\end{array}$ & $\begin{array}{c}\text { Teacher } \\
\%\end{array}$ & $\underset{\%}{\text { Neighbor }}$ & $\begin{array}{c}\text { No } \\
\text { one } \\
\%\end{array}$ \\
\hline \multicolumn{11}{|l|}{ Sex } \\
\hline Male & 47 & 10 & 25 & 12 & 6 & 4 & 64 & 2 & 1 & 22 \\
\hline Female & 42 & 2 & 29 & 18 & 8 & 7 & 65 & 1 & 2 & 22 \\
\hline \multicolumn{11}{|l|}{$\begin{array}{l}\text { Population } \\
\text { group }\end{array}$} \\
\hline African rural & 33 & 5 & 38 & 17 & 5 & 3 & 69 & 1 & 0 & 23 \\
\hline African urban & 43 & 6 & 25 & 15 & 8 & 3 & 62 & 3 & 2 & 28 \\
\hline Coloured & 71 & 11 & 9 & 10 & 0 & 23 & 41 & 2 & 0 & 14 \\
\hline Asian & 61 & 6 & 21 & 11 & 1 & 13 & 74 & 2 & 1 & 2 \\
\hline White & 60 & 14 & 19 & 3 & 3 & 15 & 70 & 1 & 1 & 5 \\
\hline All & 45 & 6 & 27 & 15 & 6 & 5 & 65 & 2 & 2 & 22 \\
\hline
\end{tabular}


Respondents clearly have close relationships with the persons they named; most said they trust, talk with, and discuss problems with this person. Nonetheless, respondents are much less likely to communicate about sexual topics with family members than with someone outside the family. While over three-quarters ( 82 percent and 77 percent, respectively) said they can talk about partners and sex with the person outside the family, only about half said they can talk about a boy/girlfriend (53 percent) and sex (43 percent) with the person they feel closest to within their family.

Schooling is very important to the people the adolescents feel close to. For those inside the family, 97 percent of the respondents said this person would want them to finish school and 94 percent said this person would want them to continue after high school. For those outside the family, 87 percent of respondents said this person would want them to finish school and 94 percent said this person would want them to continue after high school. The vast majority of respondents said that both the person within the family ( 91 percent) and outside the family ( 87 percent) they are closest with would disapprove of them becoming pregnant or getting someone pregnant while still in school.

\section{Table 7 Adolescents agreeing with the statement for the person in and} outside the family they feel closest to

\begin{tabular}{lcc}
\hline & $\begin{array}{c}\text { Person in the } \\
\text { family } \\
(\mathbf{n = 2 , 8 8 7 )} \\
\%\end{array}$ & $\begin{array}{c}\text { Person outside } \\
\text { the family } \\
(\mathbf{n = 2 , 4 1 3 )} \\
\%\end{array}$ \\
\hline He/she talks with me a lot & 93 & 95 \\
I feel very close to him/her & 99 & 97 \\
I trust him/her & 98 & 95 \\
I can talk to him/her about my problems & 90 & 94 \\
The two of us argue a lot & 47 & 48 \\
I am able to talk to him/her about boy/girlfriends & 53 & 82 \\
I can talk to him/her about issues regarding sex & 43 & 77 \\
He/she would strongly disapprove of me getting & & 87 \\
pregnant/getting a girl pregnant while still in \\
school
\end{tabular}




\section{Connectedness to community}

Connectedness to the community and social cohesion are measured through perceptions of community safety as reported in the community study, by the adolescents in the individual survey, and by the extent to which the adolescents interviewed believe that the residents of their community look after and support one another. To gauge community safety, interviewers asked community respondents whether they feel safe when walking in the community, whether they think there are unsafe areas, and if there are gangs locally active. In addition, interviewers asked how often they see police on duty in the community. Finally, since the presence of loitering people generally is seen as making the community unsafe, interviewers observed this for assessment.

Overall, rural Africans feel safer walking through their community at night than urban Africans (see Table 8). Among the urban communities, people from the mixed and White communities feel least safe walking outside at night. On average, people from the Asian and rural African communities feel safest walking through their community at night. When asked if there are unsafe areas in their community, rural Africans are most likely to think that this is not the case. Whites are most likely to think that there are areas in their community that are unsafe. Gang activity is most prevalent in both the rural and urban African communities, although worse in the urban areas. Similarly, loitering is most visible in the urban African communities, while it is least obvious in the White areas. Finally, visibility of police on duty is highest in the Asian communities, while lowest in the White communities.

Table 8 Community perceptions of neighborhood safety

\begin{tabular}{|c|c|c|c|c|c|}
\hline & $\begin{array}{c}\text { Neighborhood } \\
\text { is safe to walk } \\
\text { through at } \\
\text { night } \\
\text { (\% who agree) }\end{array}$ & $\begin{array}{c}\text { There are no } \\
\text { unsafe areas } \\
\text { in the } \\
\text { neighborhood } \\
\text { (\% who agree) }\end{array}$ & $\begin{array}{c}\text { There is no } \\
\text { gang activity } \\
\text { in the } \\
\text { neighborhood } \\
\text { (\% who agree) }\end{array}$ & $\begin{array}{l}\text { Average } \\
\text { number of } \\
\text { loitering } \\
\text { groups }\end{array}$ & $\begin{array}{l}\text { \% who see } \\
\text { police on duty } \\
\text { at least once a } \\
\text { day or week in } \\
\text { neighborhood }\end{array}$ \\
\hline \multicolumn{6}{|c|}{ Population group } \\
\hline $\begin{array}{l}\text { African rural } \\
(n=16) \\
\text { African urban }\end{array}$ & 50 & 74 & 63 & 5 & 60 \\
\hline$(n=61)$ & 38 & 53 & 58 & 9 & 53 \\
\hline Asian $(n=14)$ & 48 & 52 & 85 & 3 & 75 \\
\hline White $(n=7)$ & 33 & 46 & 88 & 2 & 32 \\
\hline Mixed $(n=15)$ & 28 & 57 & 91 & 4 & 52 \\
\hline All $(n=113)$ & 40 & 56 & 68 & 7 & 55 \\
\hline
\end{tabular}

Note: Percentages reported in the table are the averages of the percentage of agreeing respondents in each community by population group and $\mathrm{n}$ refers to the number of communities in each population group.

Interviewers asked adolescents to agree or disagree with a series of five statements about how connected they feel to their community (see Table 9). Nearly 90 percent of respondents feel safe in their community during the day. Most respondents also feel that adults in their neighborhood help other families in need (78 percent) and that people in their neighborhood trust one another (62 
percent). Nearly two-thirds of respondents said that they have many friends in the community. Nonetheless, 42 percent thought they would be much happier if they lived in another community. Africans are least likely to have many friends in the neighborhood and the most likely to agree that they would be happier if they lived elsewhere.

Males seem to have a greater connection to their community than females; they are more likely to report help and trust among community members and to have many friends, and less likely to say that they would feel happier if they lived in another community. Africans are more likely than other population groups to report that they feel safe in their neighborhoods and that neighbors are supportive. However, they are much less likely to say they have many friends and more likely to think they would be happier if they lived in another community. The latter sentiment is likely to be affected by the lack of infrastructure in the African areas, as noted earlier, as well as their relationships in the community.

Table 9 Connections to the community $(n=3,096)$

\begin{tabular}{|c|c|c|c|c|c|c|c|c|}
\hline \multirow[b]{2}{*}{ Percent who agree } & \multicolumn{2}{|c|}{ Sex } & \multicolumn{5}{|c|}{ Population group } & \multirow[t]{2}{*}{ All } \\
\hline & Male & Female & $\begin{array}{c}\text { African } \\
\text { rural }\end{array}$ & $\begin{array}{c}\text { African } \\
\text { urban }\end{array}$ & White & Asian & Coloured & \\
\hline $\begin{array}{l}\text { I feel safe walking } \\
\text { around in my } \\
\text { neighborhood/ } \\
\text { community during } \\
\text { the day }\end{array}$ & 92 & 83 & 90 & 85 & 88 & 91 & 93 & 87 \\
\hline $\begin{array}{l}\text { The adults in my } \\
\text { neighborhood/ } \\
\text { community will help } \\
\text { other families when } \\
\text { they are in trouble }\end{array}$ & 82 & 75 & 84 & 76 & 73 & 83 & 66 & 78 \\
\hline $\begin{array}{l}\text { People in my } \\
\text { neighborhood trust } \\
\text { one another }\end{array}$ & 67 & 56 & 65 & 57 & 71 & 64 & 50 & 61 \\
\hline $\begin{array}{l}\text { I have many friends } \\
\text { in my } \\
\text { neighborhood/ } \\
\text { community }\end{array}$ & 77 & 49 & 52 & 60 & 65 & 87 & 71 & 62 \\
\hline $\begin{array}{l}\text { I would be much } \\
\text { happier if I lived in } \\
\text { another community }\end{array}$ & 38 & 44 & 52 & 45 & 14 & 24 & 24 & 42 \\
\hline
\end{tabular}

In the community intercept survey, we asked community members about their perception of the risk of adolescents in their neighborhood to HIV infection. We also included a number of questions on attitudes toward people living with HIV/AIDS to gauge the extent of supportive or discriminatory community-level attitudes. The results are shown in Table 10. A significant number 


\section{H ${ }^{\text {rizons }}$}

of adults in the community believe that youth in their neighborhood are at high risk of HIV infection. This was particularly the case in the urban African communities, where more than half believe this. Asian neighborhoods are most likely to think that youth from their areas are at low risk of HIV infection.

Most respondents think HIV-infected students should be allowed to remain in school, though the attitude is less prevalent in the Asian communities. Urban African community members expressed a greater willingness to share experiences about HIV than other respondents. Just under half of urban Africans said that if a family member became infected with HIV, they would want it to remain a secret. Among the other population groups, almost three-quarters said they would want the HIV-positive status of a family member to remain hidden from the community. While many respondents would not want it known publicly that someone in their family is HIV-positive, they themselves would be willing to care for an infected family member.

The results document the magnitude and unevenness of the HIV/AIDS epidemic in KwaZuluNatal. Nearly half of African respondents in both rural and urban areas know of someone in their neighborhood who has died of AIDS. However, only 7 percent of Asians and 5 percent of Whites report knowing someone from their neighborhood who has died of AIDS. 
Table 10 Community attitudes about the risk of HIV infection among youth in their community and toward people infected with HIV/AIDS $(n=4,469)$

\begin{tabular}{|c|c|c|c|c|c|}
\hline & $\begin{array}{c}\text { Rural African } \\
\begin{array}{c}(\mathrm{n}=630) \\
\%\end{array}\end{array}$ & $\begin{array}{c}\text { Urban African } \\
(n=2,444) \\
\%\end{array}$ & $\begin{array}{c}\text { Asian/ } \\
\text { Coloured } \\
(n=794) \\
\%\end{array}$ & $\begin{array}{c}\text { White } \\
(n=601) \\
\%\end{array}$ & $\begin{array}{c}\text { All } \\
(n=4,469) \\
\%\end{array}$ \\
\hline $\begin{array}{l}\text { Adolescents in } \\
\text { neighborhood are } \\
\text { at low risk }\end{array}$ & 42.7 & 19.8 & 65.0 & 42.2 & 33.4 \\
\hline $\begin{array}{l}\text { Adolescents in } \\
\text { neighborhood are } \\
\text { at medium risk }\end{array}$ & 20.5 & 25.2 & 18.3 & 33.5 & 24.4 \\
\hline $\begin{array}{l}\text { Adolescents in } \\
\text { neighborhood are } \\
\text { at high risk }\end{array}$ & 36.8 & 55.0 & 16.7 & 24.3 & 42.2 \\
\hline $\begin{array}{l}\text { Think HIV-positive } \\
\text { student should } \\
\text { remain in school }\end{array}$ & 78.4 & 81.1 & 66.6 & 84.9 & 78.7 \\
\hline $\begin{array}{l}\text { Would want to keep } \\
\text { it secret if a } \\
\text { member of his/ } \\
\text { her family } \\
\text { contracted HIV }\end{array}$ & 73.5 & 48.5 & 71.9 & 77.6 & 59.9 \\
\hline $\begin{array}{l}\text { Willing to take care } \\
\text { of relatives with } \\
\text { AIDS }\end{array}$ & 93.6 & 87.4 & 86.6 & 95.9 & 89.3 \\
\hline $\begin{array}{l}\text { Knows someone in } \\
\text { the neighborhood } \\
\text { who died of AIDS }\end{array}$ & 46.0 & 50.5 & 7.0 & 5.2 & 36.1 \\
\hline
\end{tabular}

\section{Membership in neighborhood/ community associations}

Interviewers asked adolescent respondents about their membership in a variety of neighborhood and community associations in order to assess how active they are in community activities, as well as to gauge their exposure to other possible outlets of information and services on reproductive and sexual health. As can be seen in Table 11, membership in sports groups is the most common (29 percent), followed by dancing/singing/music groups (15 percent), study groups (12 percent), religious groups with mixed adult and youth membership (11 percent), and youth religious groups (9 percent). 
Table 11 Membership in associations $(n=3,096)$

\begin{tabular}{lc}
\hline & $\%$ \\
\hline Sports group & 29 \\
Study group & 12 \\
Dancing/singing/music/choir group & 15 \\
Religious group & 11 \\
Religious youth group & 9 \\
Savings/stokvel & 4 \\
Community garden group & 1 \\
Sewing group & 1 \\
Other youth group & 2 \\
\hline
\end{tabular}

Among the four most popular groups, some differences are observed by demographic characteristics. Sports groups are most popular among males (44 percent), Africans (30 percent), Whites (33 percent), and 14-15-year-olds (34 percent). Study groups are most popular among males (14 percent), Africans (12 percent), Asians (12 percent), urban residents (15 percent), and 16-22 year olds (13 percent). Dancing/musical groups are most popular among females (19 percent), Africans (19 percent), and 14-19-year-olds (16 percent). Religious groups are most popular among Asians ( 31 percent), Whites (20 percent) and urban residents (14 percent). There is no difference in religious group membership by age or sex (data not shown).

To complement information from the individual questionnaire, interviewers asked community members about the availability of clubs and groups for youth in the community. Interviewers also asked community respondents to indicate from a list which activities they participate in and if youth also participate. If at least one respondent reported participation in an activity and reported that youth could and did participate as well, we considered this activity available to youth in this community. In the majority of the communities - the exception being White communitiesrespondents identified at least one sports club. Half of the communities have religious groups in which youth are active. These are more common in African and White communities and less common in Asian neighborhoods. In about a quarter of the White and African urban communities and less often in other communities, respondents identified a youth group.

These results provide important indicators of environments that are supportive of or detrimental to adolescents' transitions. The data presented in this section suggest that relationships with family members continue to be highly valued by youth, while many youth distrust people outside of the family; for example, 22 percent of respondents said they do not feel close to any person outside of the family. At the same time, more respondents report that they are more comfortable talking about romantic and sexual relationships and sex with someone outside their family than with people in the family they feel close to. Respondents had generally positive attitudes about the safety and social support in their neighborhoods, though more than 40 percent of adolescents feel they might be happier if they lived elsewhere. While many communities seem aware of the risk of HIV 
infection for their youth, there is generally a reluctance to share personal experiences that may limit the potential for social support. Finally, looking to formal community structures, sports are by far the most common activities that bring youth together-either in their community or elsewhere.

Religious youth groups and general youth groups are also places where youth come together. 


\section{School Context and Life Skills Programme}

School contextual variables affect the quality of adolescents' connection with their peers and family, vital relationships in the mediation between risk-taking and reproductive health outcomes. Additionally, the extent to which a youth individual feels connected to his or her school may also influence how much he or she participates and enacts lessons learnt at school (e.g., through the Life Skills Programme). Finally, a fundamental measure of the effectiveness of the Life Skills Programme is the proportion of students who are exposed to the programme and the content and intensity of that exposure.

\section{School environment}

Respondents who had attended either primary or secondary school since January $1998(\mathrm{n}=2,448)$ were asked a number of questions regarding their perception of their school's environment (see Table 12). The overall impression is one of disorder. Seventy percent of respondents reported that their classrooms are noisy, 45 percent said they are crowded, and 39 percent said they are dirty. More rural respondents (53 percent) said their classrooms are crowded than did the urban respondents (42 percent). Almost half (48 percent) of the respondents said they do not have access to all required textbooks. One-quarter of respondents stated their teachers are often absent, while eight percent stated drunk teachers are a problem in their school. One-third of urban respondents and 12 percent of rural respondents stated there is drug dealing in their schools.

Well over half (66 percent) of the respondents said they have been punished in school at some point. More males ( 74 percent) said they have been punished than females (58 percent), as well as more rural (83 percent) than urban students (60 percent). Of those punished, a large proportion (78 percent) said they were either hit or caned. While this type of corporal punishment was reported among 69 percent of urban respondents, nearly all (98 percent) rural respondents who had been punished at school were either hit or caned. Our data represent past experience of our respondents, and we did not collect information on when the physical punishment occurred. The national Schools Act banned corporal punishment in schools in 1997. The ruling has been unwelcome by some educators, as evidenced by the (unsuccessful) challenge in the courts brought by Christian Education South Africa in 1999 (Travers 1998; Rickard 1999), and practice may take longer to change than policy.

Only a minority of respondents (16 percent) think males and females are treated equally at their schools. Among those who stated that boys and girls are treated inequitably, three-quarters of respondents think girls are treated more favorably. Boys are more likely to report that girls receive more favorable treatment from teachers. Few respondents reported they experience sexual harassment from other students (11 percent) or teachers (5 percent) or that it is a problem in their school. More females and urban school goers perceive that sexual harassment by other students and teachers takes place in their school than do males and rural students. 
Table 12 Percent of students who reported various school problems (of those who have attended primary or secondary school since January 1998)

\begin{tabular}{|c|c|c|c|c|c|}
\hline & \multicolumn{2}{|c|}{ Sex } & \multicolumn{2}{|c|}{ Residence } & \multirow{2}{*}{$\begin{array}{l}\text { All } \\
\%\end{array}$} \\
\hline & $\begin{array}{c}\text { Male } \\
\%\end{array}$ & $\begin{array}{c}\text { Female } \\
\%\end{array}$ & $\begin{array}{c}\text { Urban } \\
\%\end{array}$ & $\begin{array}{c}\text { Rural } \\
\%\end{array}$ & \\
\hline Dirty classrooms & 37 & 40 & 41 & 31 & 38 \\
\hline Crowded classrooms & 41 & 48 & 42 & 53 & 45 \\
\hline Noisy classrooms & 74 & 67 & 71 & 68 & 70 \\
\hline Teachers often absent from classrooms & 20 & 31 & 25 & 28 & 26 \\
\hline Drunk teachers & 6 & 11 & 9 & 6 & 8 \\
\hline Percent who do not have access to all books & 49 & 46 & 48 & 46 & 48 \\
\hline Has been punished in school & 74 & 58 & 60 & 83 & 66 \\
\hline $\begin{array}{l}\text { Has been hit or caned for punishment? } \\
\text { (of those punished, } n=1,606 \text { ) }\end{array}$ & 81 & 74 & 69 & 98 & 78 \\
\hline Students threaten teachers & 16 & 26 & 24 & 14 & 21 \\
\hline Drug dealing & 27 & 26 & 31 & 12 & 26 \\
\hline Bad security just outside school & 19 & 23 & 21 & 22 & 21 \\
\hline Teachers treat boys and girls inequitably & 15 & 16 & 19 & 6 & 16 \\
\hline $\begin{array}{l}\text { Percent who answered girls are treated more } \\
\text { favorable (of those who perceive inequity, } n=254 \text { ) }\end{array}$ & 87 & 69 & 77 & 83 & 78 \\
\hline Sexual harassment by students & 8 & 13 & 12 & 6 & 11 \\
\hline Sexual harassment by teachers & 3 & 7 & 6 & 2 & 5 \\
\hline
\end{tabular}

\section{Connectedness to school}

Respondents who have attended secondary school since January $1998(n=2,415)$ were asked a number of questions to assess the connectedness they feel to their schools (see Table 13).

Notwithstanding the many enumerated failings of their schools listed above-such as poor physical conditions, absent and/or drunk teachers, and punitive school authorities-most respondents described their school as a place where they have friends and that teachers and principals care for their charges. Three-quarters of respondents said they have many friends at the school they attend. Almost all the students think both the teachers at their schools and the principal care about the students. Overall, 85 percent stated there is a teacher at their school they could talk to. Sixty-three percent stated they participate in extracurricular activities, strengthening their connection with their schools.

One-third of all respondents reported they would be happier if they attended a different school; this sentiment is more common among rural than urban respondents. The majority of respondents said they feel safe at their schools, though more than one-quarter feel there is considerable violence among students at their schools. This seeming contradiction suggests that while they have 


\section{Horizons}

witnessed or heard of violent acts within their school, our respondents feel that students outside of their immediate sphere perpetuate this violence.

There is little difference in the reports of connectedness to school among males and females. However, there are differences in the degree of connectedness to school among population groups. Asian and White students are more likely than Coloured or African students to say that they have many friends at their school and that they participate in extracurricular school activities. African students are much more likely than other students to feel that they would be happier if they attended another school. Asian students are most likely to agree that there is considerable violence in their schools. 
Table 13 Connected to school: percent of students who agree (of those who have attended secondary school since January 1998)

\begin{tabular}{|c|c|c|c|c|c|c|c|c|}
\hline & \multirow{2}{*}{\multicolumn{2}{|c|}{ Sex }} & \multicolumn{5}{|c|}{ Population Group and Residence } & \multirow{3}{*}{$\begin{array}{l}\text { All } \\
\%\end{array}$} \\
\hline & & & \multirow{2}{*}{$\begin{array}{c}\text { Rural } \\
\text { African } \\
\%\end{array}$} & \multicolumn{4}{|c|}{ Urban } & \\
\hline & $\begin{array}{c}\text { Male } \\
\%\end{array}$ & $\begin{array}{c}\text { Female } \\
\%\end{array}$ & & $\begin{array}{l}\text { African } \\
\%\end{array}$ & $\begin{array}{c}\text { Coloured } \\
\%\end{array}$ & $\begin{array}{l}\text { Asian } \\
\%\end{array}$ & $\begin{array}{l}\text { White } \\
\%\end{array}$ & \\
\hline $\begin{array}{l}\text { I have many friends at this } \\
\text { school }\end{array}$ & 77 & 68 & 61 & 69 & 89 & 96 & 94 & 73 \\
\hline $\begin{array}{l}\text { The teachers at this school care } \\
\text { about the students }\end{array}$ & 93 & 92 & 94 & 93 & 83 & 88 & 93 & 93 \\
\hline $\begin{array}{l}\text { The principal at this school } \\
\text { cares about the students }\end{array}$ & 93 & 92 & 95 & 93 & 86 & 89 & 84 & 92 \\
\hline There is a teacher at this school & & & & & & & & \\
\hline $\begin{array}{l}\text { I can talk to if I have a } \\
\text { problem }\end{array}$ & 85 & 86 & 80 & 87 & 85 & 86 & 94 & 85 \\
\hline $\begin{array}{l}\text { I participate in extracurricular } \\
\text { school activities }\end{array}$ & 67 & 60 & 62 & 59 & 63 & 78 & 72 & 63 \\
\hline $\begin{array}{l}\text { I would be much happier if I } \\
\text { attended another school }\end{array}$ & 33 & 35 & 45 & 37 & 18 & 16 & 10 & 34 \\
\hline I feel safe at school & 89 & 84 & 87 & 86 & 86 & 82 & 94 & 86 \\
\hline $\begin{array}{l}\text { There is considerable violence } \\
\text { among students at this } \\
\text { school }\end{array}$ & 27 & 27 & 25 & 22 & 31 & 52 & 23 & 27 \\
\hline Number of respondents & 1,135 & 1,280 & 590 & 1,320 & 35 & 330 & 140 & 2,415 \\
\hline
\end{tabular}




\section{Hgrizons}

\section{Exposure to Life Skills}

Addressing adolescents' exposure to life skills is essential for evaluating the effectiveness of the Life Skills Programme. The information provided by adolescents complements data on the availability of Life Skills in secondary schools in Durban and Mtunzini collected from the principals of those schools (Macintyre et al. 2000). This study of the availability of Life Skills found that the definition of what constitutes a Life Skills Programme is clearly diverse. When the interviewers asked principals whether their schools offer Life Skills instruction and allowed them to use their own definition of what constitutes a Life Skills Programme, 60 percent of the school emerged as offering some kind of programme in Life Skills. When the interviewers asked the principals to provide information on the 11 topics covered by the DoE curriculum, 95 percent of schools are found to offer their students some form of instruction in these areas. But only 37 percent of the schools offer all 11 topics in some way or other, and only 18 percent of schools offer Life Skills through separate or integrated classes. Students in schools with a majority ( $>75$ percent) of white students or students in mixed schools are most likely to be offered a Life Skills Programme where the essential topics are covered. Least likely to receive Life Skills training are students in schools with a predominantly African student body ( $>75$ percent). The schools that teach Life Skills tend to be those that require higher fees and other parental contributions, have more facilities, and have a higher matriculation pass rate.

A number of factors have been identified that contribute to the uneven distribution of Life Skills among schools. These include the legacy of the inequitable education system that existed under apartheid, reorganization of the educational system after Life Skills teachers had been trained, disruption of the plan for introducing Life Skills in schools, and an educational policy against imposing fixed curriculums on schools and teachers (McCauley 2001).

Respondents who were currently in school or who had been to school since January 1998 were asked whether their school offered a Life Skills Programme and which Life Skills subjects have been offered in their classroom (see Tables 14 and 15). Overall, over half (60 percent) of the respondents said they have a Life Skills or life orientation/sex education programme at their school. Just over half (54 percent) of the youngest age group (14-15-year-olds) reported that they have a Life Skills programme at their school, while 63 percent of the 16-19 year olds have such classes. This difference most likely reflects the age at which such programmes are taught at each school. Only about two of five rural African youth attend a school with a Life Skills Programme. Almost three in five Coloured and Asian respondents indicated that their school offers Life Skills; twothirds of urban African respondents attend school with a Life Skills Programme, and among Whites, 85 percent reported their school offers a Life Skills Programme.

In aggregate, these results are consistent with the reports from principals about the prevalence and distribution of Life Skills Programmes. Subsequent analysis will match the reports of the availability of Life Skills provided by students with the data reported by the school principal. 
Table 14 Exposure to programme among respondents currently in school or attended secondary school since January $1998(n=2,409)$

\begin{tabular}{|c|c|c|c|c|}
\hline & $\begin{array}{c}\text { Life Skills } \\
\text { Programme at } \\
\text { school } \\
\%\end{array}$ & $\begin{array}{c}\text { Exposed to } \\
\text { eight core } \\
\text { topics* } \\
\%\end{array}$ & $\begin{array}{c}\text { Exposed to } \\
\text { all } 13 \text { topics }{ }^{+} \\
\%\end{array}$ & $\begin{array}{c}\text { No discussion of } \\
\text { any of the } 13 \\
\text { topics } \\
\%\end{array}$ \\
\hline \multicolumn{5}{|l|}{ Sex } \\
\hline Male & 63 & 33 & 24 & 15 \\
\hline Female & 57 & 19 & 13 & 19 \\
\hline \multicolumn{5}{|l|}{ Age } \\
\hline $14-15$ & 54 & 19 & 13 & 21 \\
\hline $16-19$ & 63 & 28 & 20 & 14 \\
\hline $20-22$ & 59 & 31 & 23 & 20 \\
\hline \multicolumn{5}{|l|}{$\begin{array}{l}\text { Population } \\
\text { group }\end{array}$} \\
\hline $\begin{array}{l}\text { Urban } \\
\text { African }\end{array}$ & 65 & 31 & 26 & 18 \\
\hline $\begin{array}{l}\text { Rural } \\
\text { African }\end{array}$ & 43 & 17 & 6 & 26 \\
\hline Coloured & 57 & 46 & 16 & 3 \\
\hline Asian & 58 & 23 & 16 & 2 \\
\hline White & 85 & 20 & 4 & 6 \\
\hline All & 60 & 26 & 18 & 17 \\
\hline
\end{tabular}

To measure the actual content of material that the adolescents were exposed to, respondents were read a list of topics and were asked if they recalled each subject being discussed in class during their last year at school. The topics (listed in Table 15) correspond to those outlined by the DoE's curriculum on Life Skills education (South Africa Department of Health and South Africa Department of Education 1997/98). These topics were asked of all adolescents who had attended secondary school at any time since January 1998, regardless of whether the respondent reported that their school offered a Life Skills Programme, as Life Skills topics are also taught as part of other classes.

The Life Skills topics recalled most frequently are "HIV/AIDS - prevention and transmission" (70 percent), "drugs and alcohol" (62 percent), "reproductive biology" (61 percent), and "why and when to use a condom" (61 percent). The topics that appear to be discussed least in class are "sexually transmitted diseases - preventions/symptoms" (52 percent); "self-esteem, decision making and assertiveness" (52 percent); and "relationships - communication and negotiation with your partner" (47 percent). Eighteen percent of the respondents said they have been exposed to all 13 Life Skills topics at school. 


\section{Hgrizons}

From the 13 topics included in the South African curriculum, we have identified eight as the "most essential subjects" to be covered in any Life Skills education programme: self-esteem, understanding sexuality issues, contraception, negotiation within relationships, prevention of HIV/AIDS, general STD prevention, how to use a condom, and why and when to use a condom. The selection of the eight core topics is based on a combination of a meta-analysis of the literature, the offerings in the national Life Skills Programme curriculum, and expert opinion. Among the topics included in the national Life Skills education programme, exposure to these topics is regarded as most essential for effective programmes promoting the reduction of risky sexual behaviour, the prevention of HIV transmission, and unintended pregnancy.

Overall, less than a quarter of the respondents recalled having discussed all eight core Life Skills topics during their last year of school. More males (33 percent) than females (19 percent) reported discussing all eight topics at school. As expected, the proportion of respondents who have been exposed to all eight topics at school increases with age (19 percent of the 14-15-year-olds, 28 percent of the 16-19-year-olds, and 31 percent of the 20-22-year-olds). Coloured respondents (46 percent) most frequently said they had covered all eight topics, followed by urban Africans (31 percent), Asians (23 percent), Whites (20 percent), and rural Africans (17 percent).

Seventeen percent of the respondents said they have covered none of the 13 Life Skills topics at school. One-quarter of rural African respondents, compared to less than 20 percent of the urban Africans and less than 10 percent of the other population groups, have had none of the 13 topics at school. 


\begin{tabular}{lc} 
Table $15 \begin{array}{l}\text { Percent reporting various Life Skills topics presented in } \\
\text { classroom, among those who were currently in school or } \\
\text { attended secondary school since January }\end{array}$ \\
\begin{tabular}{lc} 
1998 (n = 2,409) \\
\hline Topics
\end{tabular} & $\%$ \\
\hline HIV/AIDS transmission and prevention* & 70 \\
Drugs and alcohol & 62 \\
Reproductive biology (i.e., male/female parts of the body) & 61 \\
Why and when to use a condom* & 61 \\
Contraception/how to prevent pregnancy & 58 \\
Understanding sexuality - relationships with the opposite sex* & 57 \\
Violence and sexual abuse - child abuse, incest, rape, and & 57 \\
coercion & 56 \\
Looking after people with AIDS & 56 \\
How to use a condom* & 55 \\
Human growth and development and the life cycle & 52 \\
Self-esteem, assertiveness, and decision making & \\
Sexually transmitted diseases - prevention/symptoms & 52 \\
Relationships - communication and negotiation with your partner* & 47 \\
& \\
& * Subjects considered most essential for effective programmes promoting the reduction of \\
risky sexual behaviour and the prevention of HIV transmission and unintended pregnancy.
\end{tabular}

As part of our assessment of respondents' exposure to Life Skills education, we also explored who presented the information and how much time in the previous four weeks had been devoted to Life Skills topics. Respondents could report multiple presenters. Teachers and school counselors are the main sources of Life Skills education (69 percent). This is followed by nurses/health workers (39 percent), adults from outside the school (15 percent), and peer educators (4 percent). Life Skills classes are given as special presentations taught as separate subjects or integrated into other subjects. Of those respondents who had Life Skills in school, 58 percent said that one hour or less in the last four weeks was devoted to Life Skills topics, and 23 percent reported two hours for Life Skills. Nineteen percent report three hours or more.

Nearly half (42 percent) of the respondents said they have also been exposed to Life Skills training/ discussions outside of school within the last four weeks through TV, radio, special events, and/or group presentations. Soul City is the most frequently mentioned provider of these activities/promotions ( 41 percent), ${ }^{8}$ followed by clinics and nurses ( 25 percent), DramAidE ( 4 percent $){ }^{9}$ and others (18 percent). Of those who said they have been exposed to Life Skills outside

\footnotetext{
${ }^{8}$ Soul City is a multi-faceted communications strategy which seeks the to use "edutainment" media in bringing about social change.

${ }^{9}$ DramAidE is an AIDS, Life Skills and sexuality education programme which has been operating in KwaZulu Natal since 1991.
} 


\section{Hgrizons}

of school, nearly half said it was between one and two hours over the previous four weeks, while over a third said they had more than two hours (data not presented in table).

Exposure to the programme is important but not necessarily sufficient to have an impact. The quality of the teaching and both the content and the interaction between teacher and student are important determinants of impact. Our data tell us little about the quality of Life Skills education in the Durban and Mtunzini schools. We did learn that in most schools (77 percent) with Life Skills instruction, at least one or two teachers had received training to teach Life Skills. However, many principals considered the general teacher training provided at a university or by the DoE as sufficient preparation for teaching Life Skills; two-thirds of principals in schools where teachers are trained mentioned this training when asked where the teachers were trained. Some teachers (6 percent) are trained by the DoH, by the NGOs DramAidE ( 7 percent), Planned Parenthood (3 percent), or others ( 9 percent). The majority (67 percent) was trained less than five years ago.

Few schools with a Life Skills Programme receive funding for the programme; 82 percent do not receive any outside funding. The DoE provided funding for Life Skills training to 12 percent of the schools and the DoH to 1 percent. Other sources of funding include government subsidies ( 2 percent), the child welfare department ( 0.6 percent), or external private sources ( 2 percent). 


\section{Risk Taking and Health-seeking Knowledge and Behavior}

\section{HI V knowledge, stigma, perception of risk, and testing}

Nearly all respondents (99 percent) had heard of HIV and most (94 percent) spontaneously mentioned that HIV could be transmitted through sexual intercourse (Table 16). More than half also knew (without prompting) that HIV could be transmitted through contact with infected blood, and one-fifth mentioned that sharing needles could transmit the virus. Somewhat surprisingly, given the discussion in the media in South Africa about making AZT available to pregnant women to prevent transmission from mother to child during pregnancy and delivery, this mode of transmission was only mentioned by 4 percent.

\begin{tabular}{lr}
$\begin{array}{l}\text { Table } \mathbf{1 6} \text { Knowledge of HIV transmission (spontaneous } \\
(\mathbf{n}=\mathbf{3 , 0 9 7 )}\end{array}$ \\
\hline & $\%$ \\
\hline Sexual intercourse & 94 \\
Blood contact & 56 \\
Sharing needles & 21 \\
Unclean medical equipment & 9 \\
Contact with infected person's toothbrush/shaving material & 8 \\
Pregnancy/birth/breast milk (MTCT) & 4 \\
Casual contact with infected person & 2 \\
Mosquito/insect bites & 1 \\
Other & 5 \\
Don't know & 2 \\
Has not heard about AIDS & 1 \\
\hline
\end{tabular}

Ninety-five percent of respondents reported that they think a person can do something to protect $\mathrm{him} /$ herself from getting HIV/AIDS. Nearly 90 percent mentioned that a person could protect himself or herself by always using condoms; one-third mentioned that people can protect themselves by abstaining from sex, 10 percent mentioned having only one partner, and 7 percent mentioned using sterilized needles (data not shown).

One out of four youth interviewed said that they know someone who died of AIDS (or they believe died of AIDS), mostly casual acquaintances or neighbors of the respondents. Only 2 percent of respondents reported that a close family member or friend died of AIDS; four percent reported the death of a more distant relative or friend.

As a measure of the extent to which a respondent held fearful and possibly stigmatizing attitudes toward people infected with HIV, we asked if the respondent would have different kinds of casual contact with somebody who is infected or they suspect is infected with HIV. Over two-thirds of the 
interviewed youth said they would engage in different types of casual contact; most are comfortable working with, sitting next to, having as a friend, and touching someone infected with HIV (see Figure 1). Respondents are less comfortable using the same toilet, sharing a bed, and particularly sharing food and utensils (about one-third said they would not do the latter). Onequarter of respondents also said an HIV-positive student should not be allowed in school. These results highlight the need for more education on modes of HIV transmission as well as the need to de-stigmatize casual contact with people living with HIV or AIDS.

\section{Figure 1 Percent reporting feeling comfortable with various types of casual contact with HIV+ person}

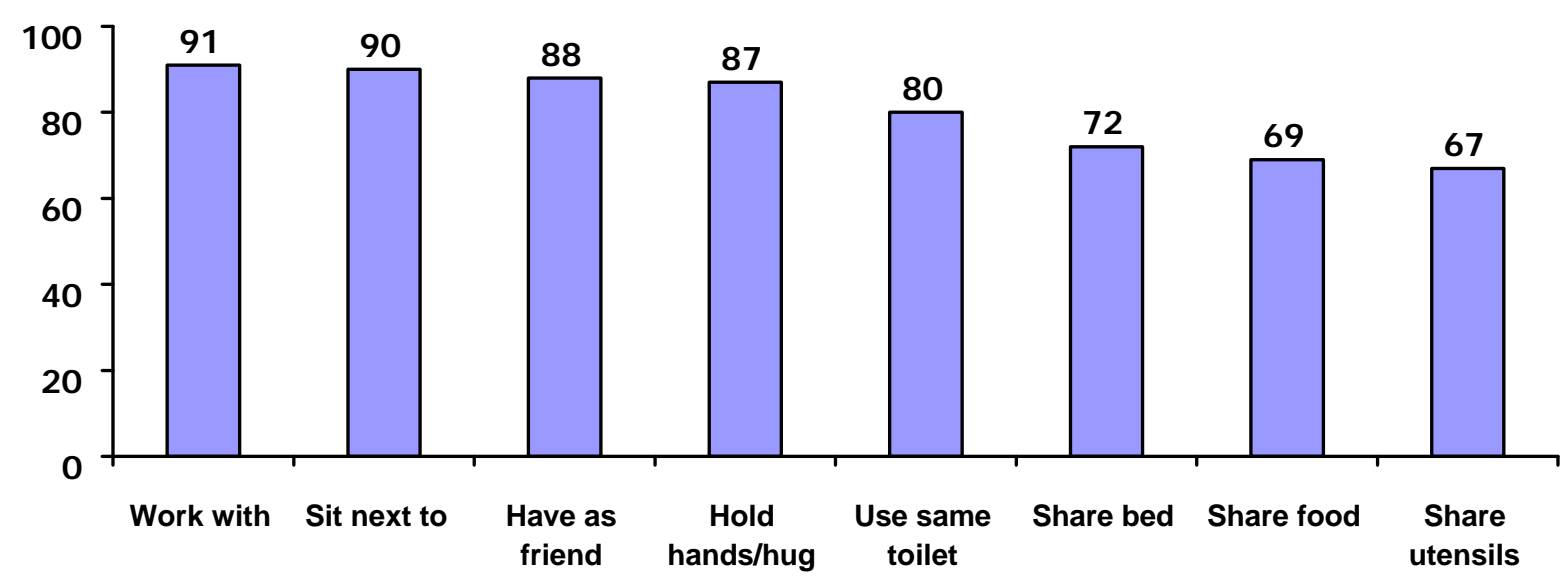

Somewhat surprisingly, given the significant media attention to youth and the HIV epidemic in South Africa, only a small proportion (11 percent) of respondents think they are at moderate or great risk of HIV (two respondents volunteered that they are HIV-positive). Among adolescents who had ever had sex, 18 percent feel at high risk of HIV infection. There are significant differences in the estimation of risk among subgroups: males, Africans and Whites, and older respondents are more likely to report themselves to be at high risk as compared to other groups. The main reasons given by those who feel that they are at low or no risk is that they are not sexually active ( 54 percent), always use condoms ( 20 percent), and have only one partner (12 percent). Those at high risk mention unprotected sex (31 percent), multiple partners ( 23 percent), and accidents (18 percent) as factors in their life that put them at risk of HIV infection.

We asked respondents to tell us if they had ever had an HIV test, after reassuring them that we were not interested in hearing the result of the test. Eleven percent said they have had an HIV test. Girls are twice as likely to have had an HIV test as boys (14 as compared to 7 percent), suggesting that many of these tests may have occurred in the context of antenatal care. Four-fifths of those who had an HIV test received the results. The most common reasons for not receiving the results 
are fear, no one offered to share the results, and they are still waiting to collect results (data not presented).

\section{Knowledge of other sexually transmitted diseases}

Knowledge of sexually transmitted diseases (STDs) (other then HIV/AIDS) was low; fewer than half of the respondents said they had "heard of diseases other than HIV/AIDS that can be transmitted through sexual intercourse." There is no difference in knowledge among males and females. White and Coloured respondents are more likely to know of other STDs than African and Asian youth. Knowledge increases with age, but still one-third of respondents ages 20-22 know of no STDs other than HIV/AIDS. Among those who know of other STDs, one in five females cannot describe a single symptom in women and one in six males cannot name any symptoms for men. These results present a considerable challenge to educate youth about STDs and encourage them to recognize symptoms and seek treatment (data not presented).

\section{Sexual experience and relationships}

Study participants were asked if they had ever had sexual intercourse, by which we explained we meant "full penetration." Only those who responded affirmatively to this question were asked additional questions about sexual initiation and recent sexual partners and activity. Since respondents may be embarrassed or reluctant to admit they are sexually active, the estimates of how many adolescents in the study population have ever had sex, when they first had sex, and the type and frequency of their recent sexual partners may be underreports. Overall, one-half of all respondents report ever having had sexual intercourse; this varies from 10 percent of 14-15-yearolds to 84 percent of 20-22-year-old respondents. To get an estimate of the timing of age of first sexual intercourse, we looked at the proportion of respondents 16 years and older who had sexual intercourse before their $16^{\text {th }}$ birthday. Overall, one-fifth of youth 16 or older had their first sexual experience before their $16^{\text {th }}$ birthday. Males and Africans initiated sex earlier than girls and other population groups (see Table 17). 
Table 17 Experience with sexual intercourse among respondents

\begin{tabular}{|c|c|c|}
\hline & $\begin{array}{c}\text { Ever had sexual } \\
\text { intercourse }(n=3,094) \\
\% \\
\end{array}$ & $\begin{array}{c}\text { Older than } 16 \text { who had sex } \\
\text { by age } 16(n=2,335) \\
\%\end{array}$ \\
\hline \multicolumn{3}{|l|}{ Sex } \\
\hline Male & 52 & 29 \\
\hline Female & 47 & 14 \\
\hline \multicolumn{3}{|l|}{ Population group } \\
\hline African rural & 52 & 36 \\
\hline African urban & 57 & 26 \\
\hline Coloured & 29 & 14 \\
\hline Asian & 23 & 7 \\
\hline White & 35 & 10 \\
\hline \multicolumn{3}{|l|}{ Age } \\
\hline $14-15$ & 10 & -- \\
\hline $16-19$ & 51 & 22 \\
\hline $20-22$ & 85 & 18 \\
\hline All & 49 & 21 \\
\hline
\end{tabular}

Slightly more than one-quarter (26 percent) of respondents had a steady boyfriend or girlfriend at the time of the study, with just 1 percent reporting that they are currently or were formerly married. Among those who had a sexual relationship in the last year, almost 90 percent of the partners were boyfriends or girlfriends, a few were spouses, and the rest were reported as either casual acquaintances or friends. Among females who had a sexual relationship in the past 12 months, 9 percent had two sexual partners in that period and 2 percent reported three or more partners. However, multiple partnerships in the past year were common for males; one-half reported two or more partners in that period and 18 percent reported having three or more sexual partners.

\section{Pregnancy preferences and knowledge of pregnancy risks}

The majority of respondents ( 84 percent) said that discovering they are pregnant or had impregnated their partner in the next few weeks would be a big problem (see Table 18). As expected, discovering pregnancy in the next few weeks is considered more problematic by 14-15 year olds ( 95 percent) and 16-19 year-olds ( 86 percent) than among $20-22$ year olds ( 71 percent). More females ( 88 percent) than males ( 80 percent) thought pregnancy to be a big problem. While all population groups believe that discovering their own or their partner's pregnancy would be a big problem, this belief is slightly more common among Whites, Asians, and rural Africans than urban Africans and Coloureds. 


\section{Table 18 Believed becoming pregnant/impregnating a girl in the} next few weeks would be a big problem

\begin{tabular}{ll}
\hline & $\%$ \\
\hline Sex & \\
Male & 80 \\
Female & 88 \\
Population group & \\
White & 90 \\
Coloured & 83 \\
Asian & 87 \\
African rural & 87 \\
African urban & 81 \\
Age & \\
$14-15$ & 95 \\
$16-19$ & 86 \\
$20-22$ & 71 \\
All & 84
\end{tabular}

Understanding what adolescents know about the risk of pregnancy and pregnancy prevention is important because this knowledge affects an individual's behavior and reflects the general state of education on reproductive health. We therefore asked participants a series of questions to gauge their knowledge of pregnancy risks, the results of which are shown in Table 19.

Participants have little knowledge ( 8 percent) of the part of the monthly menstrual cycle when a woman has the greatest chance of pregnancy. Whites have somewhat more knowledge of the fertile period, but still less than one-third of respondents correctly answered the question. Knowledge increases somewhat with age but not much. The majority of youth ( 80 percent) know that a woman could get pregnant if she has sex only once. Older, female, and White and Coloured respondents are more likely to know about this risk than other types of respondent.

Almost all respondents (99 percent) know of at least one family planning method, and most (72 percent) can name two or more. White, urban African, older, and female respondents are most likely to know of multiple family planning methods. Among respondents who know of at least one family planning method, the pill, condom, and injectable methods were most commonly mentioned; each was mentioned by well over half of all participants. These methods were followed by abstinence, non-penetrative sex, and withdrawal, each of which was mentioned by less than 6 percent of participants. 


\section{Table 19 Knowledge of pregnancy risks by selected demographic} characteristics $(n=3,097)$

\begin{tabular}{lccc}
\hline & $\begin{array}{c}\text { Which part of menstrual } \\
\text { cycle a woman has highest } \\
\text { chance for pregnancy } \\
\%\end{array}$ & $\begin{array}{c}\text { Pregnancy is } \\
\text { possible after } \\
\text { having sex once } \\
\%\end{array}$ & $\begin{array}{c}\text { At least two } \\
\text { family planning } \\
\text { methods } \\
\%\end{array}$ \\
\hline Sex & & & \\
Male & 9 & 75 & 60 \\
$\quad$ Female & 8 & 84 & 81 \\
Population group & & & 82 \\
White & 31 & 96 & 64 \\
Coloured & 10 & 100 & 54 \\
Asian & 7 & 89 & 65 \\
African rural & 6 & 74 & 77 \\
African urban & 8 & 78 & 53 \\
Age & & & 74 \\
14-15 & 6 & 66 & 84 \\
$16-19$ & 9 & 82 & 72 \\
$20-22$ & 11 & 91 & \\
All & $\mathbf{8}$ & 80 &
\end{tabular}

\section{Condoms}

Condom knowledge is assessed by a question on how confident the respondent feels that she/he knows how to use a condom effectively. Overall, 45 percent of respondents feel very confident, 15 percent are somewhat confident, and 40 percent are not confident that they could use a condom effectively. Among those who have ever had sex, 61 percent feel very confident and another 15 percent feel somewhat confident that they use a condom effectively. Males are more confident than females, and confidence about condom use increases with age.

Knowledge of a source of condoms is nearly universal (96 percent). Most respondents (90 percent) are aware that hospitals and health clinics provide condoms. Much less frequently mentioned sources are pharmacies, shops, mobile clinics, and private doctors.

Past studies have found that condoms are generally regarded in an unfavorable light; they denote mistrust, suggest infidelity (Varga 1997; Lurie et al 1997), and are found to be distasteful and offensive (Varga 1999). Among respondents in this study, however, there is general support for condoms, perhaps an indication of attitudinal changes. As can be seen in Table 20, the majority of participants disagree with the statements that condoms denote mistrust, are unnecessary in serious relationships, are difficult to carry because they show intention of having sex, cause females to lose the respect of her partner, or are embarrassing to buy or ask for. Most think condoms are easy to attain. The greatest ambivalence is whether condoms reduce sexual pleasure: 23 percent think they do, 43 percent disagree, and 35 percent are not sure. There are some significant differences in attitudes toward condoms between males and females (data not shown in table). Males are more 
likely than females to say condoms reduce pleasure and are a sign of not trusting your partner, while females are more likely than males to report that carrying a condom is difficult.

Table 20 Respondents' attitudes toward condoms ( $n=3,097)$

\begin{tabular}{lccc}
\hline & $\begin{array}{c}\text { Agree } \\
\%\end{array}$ & $\begin{array}{c}\text { Disagree } \\
\%\end{array}$ & $\begin{array}{c}\text { Don't know } \\
\%\end{array}$ \\
\hline Using a condom is a sign of not trusting your partner. & 26 & 67 & 6 \\
$\begin{array}{l}\text { When a relationship moves from casual to serious, it is } \\
\text { no longer necessary to use a condom. }\end{array}$ & 19 & 71 & 10 \\
$\begin{array}{l}\text { Carrying condoms is difficult because it makes it look } \\
\text { as if one has planned to have sex. }\end{array}$ & 39 & 54 & 7 \\
$\begin{array}{l}\text { A woman loses a man's respect if she asks him to use } \\
\text { a condom. }\end{array}$ & 14 & 77 & 10 \\
$\begin{array}{l}\text { It is embarrassing to buy or ask for condoms. } \\
\text { You can easily get condoms any time you want to. }\end{array}$ & 19 & 75 & 64 \\
Using condoms reduces sexual pleasure. & 23 & 43 & 35
\end{tabular}

One-half of adolescents who had a partner in the past year used a condom the last time they had sex. Whites (75 percent) and Asians (60 percent) are more likely to use condoms than Africans (48 percent). Boys are slightly more likely to use condoms than girls (54 versus 47 percent) and inschool adolescents are more likely to have used condoms than out-of-school youth (57 versus 44 percent). Use is not associated with age; sexually active 14-15-year-olds are as likely to use a condom as 20-22-year-olds.

\section{Family planning information and use}

For many respondents, mass media is a significant source of information on family planning. Overall 52 percent of respondents recall a family planning message on the radio in the previous month, 42 percent recall seeing a message on TV, and 32 percent recall a message from a newspaper or magazine. Urban residents, males, and older youth are most likely to hear about family planning via mass media. One-half of respondents reported that they had discussed contraception with their friends in the last six months, including seeking information and exchanging experiences. Adolescents also reported discussing contraception with their boyfriends or girlfriends (24 percent), mothers (19 percent), and siblings (16 percent). Additionally, 45 percent reported that they had heard about contraception and how to prevent pregnancy during a Life Skills class in school.

Adolescents in this population appear to be acting on their concerns about an unwanted pregnancy. We found that a majority of adolescents sexually active in the past year used contraception. 
Overall, 62 percent of sexually active youth reported using a method to prevent pregnancy the last time they had sex. Boys and girls are equally like to report use (though they reported different methods), Whites are more likely to use contraception than Africans and Asians, urban adolescents are more likely to use contraception than rural adolescents, and use increases with age (see Table 21).

Most users rely on male condoms for pregnancy protection. Respondents also reported using injectables and pills. There are marked differences in method of choice by age. Younger youth, 1415-years old, rely heavily on male condoms, with 85 percent reporting that condoms are the method they use to prevent pregnancy. Older youth appear to abandon condoms in favor of injectables and pills-in the process losing the protection from STDs offered by condoms. Africans are more likely to use injectables than other population groups, and Whites are more likely to use pills.

Table 21 Respondents who had sex in the last year who used contraception the last time they had sex and method used $(n=869)$

\begin{tabular}{|c|c|c|c|c|c|}
\hline (Among Users) & $\begin{array}{l}\text { Used any } \\
\text { method }\end{array}$ & $\begin{array}{c}\% \text { used } \\
\text { pill }\end{array}$ & $\begin{array}{c}\% \text { used } \\
\text { injectables }\end{array}$ & $\begin{array}{c}\% \text { used (male) } \\
\text { condoms }\end{array}$ & $\begin{array}{l}\% \text { used other } \\
\text { method }\end{array}$ \\
\hline \multicolumn{6}{|l|}{ Sex } \\
\hline Male & 62 & 20 & 7 & 71 & 2 \\
\hline Female & 61 & 14 & 32 & 50 & 4 \\
\hline \multicolumn{6}{|l|}{ Population group ${ }^{1}$} \\
\hline African rural & 49 & 6 & 22 & 72 & 1 \\
\hline African urban & 65 & 19 & 23 & 54 & 4 \\
\hline Asian & 64 & 8 & 2 & 84 & 6 \\
\hline White & 83 & 35 & 4 & 57 & 2 \\
\hline \multicolumn{6}{|l|}{ Age } \\
\hline $14-15$ & 49 & 3 & 6 & 85 & 6 \\
\hline $16-19$ & 59 & 13 & 19 & 66 & 2 \\
\hline $20-22$ & 66 & 23 & 23 & 50 & 4 \\
\hline All & 61 & 17 & 20 & 60 & 3 \\
\hline
\end{tabular}

\section{Alcohol and drug use}

Alcohol and drug abuse among adolescents is a problem in its own right as well as being associated with risky sexual behaviors (Jessor, Donovan, and Costa 1991; Fortenberry et al. 1997).

Participants were asked a series of questions about their alcohol and drug use in the four weeks prior to the interview. Because of social norms against adolescent use of alcohol and drugs, it is possible that participants underreported usage. Less than one-fifth of participants (17 percent) said they had consumed alcohol within the previous four weeks. Use was high among Whites (75 percent) and considerably lower among Asians (20 percent) and Africans (12 percent). Males are 
more likely than females to report alcohol use (27 and 10 percent, respectively). While few 14-15year-olds reported having used alcohol (7 percent), roughly 20 percent of 16-19-year-olds and 2022-year-olds said they had had alcoholic drinks in the previous four weeks.

Participants who had consumed alcohol within the previous four weeks were asked how many alcoholic beverages they had consumed the last time they drank. Of those who had consumed alcohol in the previous four weeks, nearly two-thirds drank three or more drinks the last time (see Table 22). While half of the women drank three or more drinks, more than two-thirds of men had consumed three drinks or more. Consumption of three drinks or more was most common among rural African youth and least common among Whites.

Participants who said they drank within the previous four weeks were asked to report where they drank most often (see Table 22). Younger participants are more likely to drink in public than older youth. African urban participants are more likely to drink in private residences than rural Africans, Asians, and Whites.

Table 22 Location of alcohol use and amount consumed among respondents who drank in the last four weeks $(n=422)$

\begin{tabular}{|c|c|c|c|}
\hline & $\begin{array}{c}\text { Drank most often } \\
\text { in private } \\
\text { residences* } \\
\%\end{array}$ & $\begin{array}{c}\text { Drank most } \\
\text { often in } \\
\text { public areas } \\
\%\end{array}$ & $\begin{array}{c}\text { Consumed } 3 \text { or more } \\
\text { drinks the last time } \\
\text { they drank } \\
\%\end{array}$ \\
\hline \multicolumn{4}{|l|}{ Sex } \\
\hline Male & 50 & 50 & 68 \\
\hline Female & 54 & 46 & 51 \\
\hline \multicolumn{4}{|l|}{ Age } \\
\hline $14-15$ & 49 & 51 & 46 \\
\hline $16-19$ & 45 & 45 & 66 \\
\hline $20-22$ & 63 & 37 & 63 \\
\hline \multicolumn{4}{|c|}{ Population group ${ }^{1}$} \\
\hline White & 37 & 63 & 56 \\
\hline Asian & 44 & 56 & 69 \\
\hline African rural & 48 & 52 & 79 \\
\hline African urban & 64 & 36 & 60 \\
\hline All & 51 & 49 & 64 \\
\hline
\end{tabular}

Only a small percentage of participants, less than 3 percent, said they had used drugs to make them feel high in the four weeks prior to the interview (see Table 23). Almost all of these respondents (95 percent) reported that the drug they had used was marijuana (data not shown in table). Of those who had used drugs, the majority were males ( 5 percent of males reported use while less than 1 percent of females had used drugs). Drug use is more common among urban than rural youth; 
among urban youth, more drug use is reported by Whites than by other population groups. Drug use increases with age, from less than 1 percent among 14-15-year-olds to 4 percent among 20-22year-olds.

\begin{tabular}{|c|c|}
\hline & $\%$ \\
\hline \multicolumn{2}{|l|}{ Sex } \\
\hline Male & 5.0 \\
\hline Female & 0.5 \\
\hline \multicolumn{2}{|l|}{ Age } \\
\hline $14-15$ & 0.7 \\
\hline $16-19$ & 2.6 \\
\hline $20-22$ & 4.2 \\
\hline \multicolumn{2}{|c|}{ Population group } \\
\hline White & 6.2 \\
\hline Coloured & 2.4 \\
\hline Asian & 2.2 \\
\hline African rural & 0.6 \\
\hline African urban & 2.9 \\
\hline All & 2.5 \\
\hline
\end{tabular}

Two percent of participants said that someone had slipped a drug into their drink without their knowledge. Nine percent know of someone who had had a drug slipped into their drink without their knowledge (data not presented in table).

We were interested in whether alcohol consumption and/or drug use is associated with sex (data not presented). Of participants who ever drank alcohol, 5 percent reported having had sex the last time they had alcohol. Of those who used drugs, 12 percent said they had had sex the last time they took drugs.

\section{Sexual abuse and violence}

Reports from various studies in South Africa show that girls often feel they have little choice but to have sex with partners, and indeed, that many first experiences may have been coerced (Wood and Jewkes 1997; Jewkes et al. 1999; Varga 1997). Those respondents who have ever had sexual intercourse $(n=1,530)$ were asked a series of questions regarding the sexual abuse and/or violence they may have experienced (see Table 24). Almost all of the male respondents (97 percent) reported they were willing participants the first time they had sexual intercourse, and none of the males reported that they were raped or forced. While just under two-thirds (66 percent) of the female respondents reported they were willing participants the first time they had sexual intercourse, 20 percent stated they were persuaded, 4 percent stated they were tricked, and 10 percent stated they were forced or raped. 
One-fifth of respondents, 8 percent of males and 29 percent of females, reported at least one act of non-consensual sexual intercourse. Twelve percent of females reported they had sexual intercourse when physically forced, hurt, or threatened, while only three percent of males reported this experience. An additional 17 percent of females and 5 percent of males reported they had tried to refuse sex unsuccessfully at some point.

Overall, a quarter of the sub-group of respondents who have ever had sexual intercourse had experienced an unwanted sexual advance; they reported a man or woman had touched them in an unwanted sexual way. There is little difference between sexes with regard to this question.

Giving or receiving gifts may be a more subtle form of coercion because it may affect the ability of young women and men to express their preferences about the type of sexual activity, its timing, or the use of safe practices when engaging in sex (Stavrou and Kaufman 2000). These respondents were asked if they had ever received or given anything in exchange for sex, such as gifts or money. Because gift giving is widely accepted as a strategy for achieving sexual goals among some youth in South Africa, youth may greatly underreport the practice to hide the fact that there is a transactional element in their relationships. Less than 10 percent of the respondents reported ever having received something for sex. Although only 4 percent of males reported they had ever received something for sex, 11 percent of females reported they had. Only three percent of the respondents reported they had ever given something for sex, with little difference observed between sexes.

Table 24 Sexual abuse and violence

\begin{tabular}{|c|c|c|c|}
\hline & $\begin{array}{c}\text { Male } \\
\% \\
(\mathbf{n}=733) \\
\end{array}$ & $\begin{array}{c}\text { Female } \\
\% \\
(\mathbf{n}=797) \\
\end{array}$ & $\begin{array}{c}\text { All } \\
\% \\
(n=1,530) \\
\end{array}$ \\
\hline \multicolumn{4}{|l|}{ The first time I had sexual intercourse: } \\
\hline I was willing & 97 & 66 & 81 \\
\hline I was persuaded & 2 & 20 & 11 \\
\hline I was tricked & 2 & 4 & 3 \\
\hline I was forced/raped & 0 & 10 & 5 \\
\hline Ever had non-consensual sex & 8 & 29 & 19 \\
\hline $\begin{array}{l}\text { Sexual intercourse when physically forced, hurt or } \\
\text { threatened }\end{array}$ & 3 & 12 & 8 \\
\hline Tried to refuse sex unsuccessfully & 5 & 17 & 11 \\
\hline $\begin{array}{l}\text { Touched by a man or women in an unwanted sexual way, } \\
\text { such as touching, kissing, grabbing or fondling }\end{array}$ & 27 & 25 & 26 \\
\hline $\begin{array}{l}\text { Received anything in exchange for sex, such as favors or } \\
\text { money }\end{array}$ & 4 & 11 & 8 \\
\hline $\begin{array}{l}\text { Gave something in exchange for sex, such as favors or } \\
\text { money }\end{array}$ & 4 & 3 & 3 \\
\hline
\end{tabular}




\section{Transitions to Adulthood}

\section{Sexual health outcomes}

\section{Sexually transmitted infections (other than HIV)}

The same sexual behaviors that put youth at risk for HIV infection also put them at risk for other sexually transmitted diseases. The prevalence of sexually transmitted diseases within the last 12 months was assessed by asking sexually active respondents who had a sexual partner within the last 12 months if they had experienced any abnormal genital discharge and/or had genital ulcers or sores (see Table 25).

Overall, 15 percent of these adolescents said they had had at least one of these symptoms (genital discharge and/or genital ulcers/sores); 13 percent had experienced abnormal genital discharge and 8 percent had experienced genital ulcers/sores. More women than men experienced at least one of these symptoms within the past year. Not all abnormal genital discharge is indicative of an STD, which in part explains the higher percentage of abnormal genital discharge reported among women.

More African adolescents said they had experienced at least one of these symptoms over the past year compared to the other population groups ( 5 percent Asian, 3 percent Whites, and no Coloured respondents). Among the 20-22-year-olds, 18 percent said they had experienced genital discharge and/or genital ulcers/sores over the past year, compared to 13 percent of 16-19-year-olds and 14 percent of 14-15-year-olds. 


\begin{tabular}{|c|c|c|c|}
\hline & $\begin{array}{c}\text { Had abnormal } \\
\text { genital } \\
\text { discharge } \\
\%\end{array}$ & $\begin{array}{c}\text { Had genital } \\
\text { ulcers/sores } \\
\%\end{array}$ & $\begin{array}{c}\text { Had STD } \\
\text { symptoms }^{*} \\
\%\end{array}$ \\
\hline \multicolumn{4}{|l|}{ Sex } \\
\hline Male & 8 & 9 & 11 \\
\hline Female & 17 & 8 & 19 \\
\hline \multicolumn{4}{|l|}{ Age } \\
\hline $14-15$ & 14 & 12 & 14 \\
\hline $16-19$ & 10 & 7 & 13 \\
\hline $20-22$ & 16 & 9 & 18 \\
\hline \multicolumn{4}{|c|}{ Population group } \\
\hline African rural & 11 & 9 & 15 \\
\hline African urban & 16 & 9 & 17 \\
\hline Coloured & 0 & 0 & 0 \\
\hline Asian & 4 & 1 & 5 \\
\hline White & 3 & 0 & 3 \\
\hline All & 13 & 8 & 15 \\
\hline
\end{tabular}

Table 26 shows the actions taken by adolescents who experienced abnormal discharge or had a genital ulcer/sore. Fifty percent of the adolescents said they informed their partner; half said they stopped having sex; while nearly a third said they used condoms when they had these symptoms. While the vast majority ( 89 percent) said they sought advice/medicine from a doctor or health worker concerning the symptoms, less than half (45 percent) received a diagnosis. Nineteen percent sought advice/medicine from a traditional healer, 17 percent sought medicine/advice from a pharmacist, and 10 percent took medication from home.

\section{Table 26 Actions taken by respondents with symptoms of} STDs in the past 12 months $(n=232)$

\begin{tabular}{ll}
\hline & $\%$ \\
\hline Tell partner about the symptoms & 58 \\
Stop having sex when having symptoms & 50 \\
Use a condom during the time of symptoms & 28 \\
Seek advice/medicine from a health worker or clinic & 89 \\
Obtain a diagnosis & 45 \\
Seek advice/medicine from a pharmacy & 17 \\
Seek advice/medicine from a traditional healer & 19 \\
Take medicine at home & 10
\end{tabular}




\section{Hgrizons}

\section{Pregnancy and childbirth}

One of the major outcome variables of interest in this study is teenage birth, particularly unwanted pregnancies, abortions, and unsafe pregnancies. Table 27 shows the proportion of females who have ever been pregnant, males who have ever made a girl pregnant, females who have given birth, and males who have fathered a child. Of all females, nearly a quarter have ever been pregnant. This is just over one half ( 52 percent) of the sexually active girls. Of those who have ever been pregnant, most ( 88 percent) said they have been pregnant once, while 12 percent have been pregnant twice. The proportion of females who have ever been pregnant is by far the highest among African respondents. As expected, the proportion of females who have ever been pregnant increases sharply with age. Only 2 percent of the 14-15-year-olds have ever been pregnant, while nearly a quarter of the 16-19-year-olds and nearly half of the 20-22-year-olds have ever been pregnant.

Among all male respondents, only 5 percent said they have ever made a girl pregnant (this is nearly 10 percent of the sexually active male population). This proportion is highest among rural African and Coloured respondents and lowest among Asian and Whites. The proportion of males who said they have ever made a girl pregnant also increased with age: 1 percent of 14-15-year-olds, 3 percent of 16-19-year-olds, and 15 percent of 20-22-year-olds reported impregnating a girl. The discrepancy in reports between females and males is most likely partly because of underreporting by males either because they do not know of a partner's pregnancy or are denying it and partly because girls' sexual partners are often much older and thus ineligible to be interviewed in the study.

Twenty-two percent of girls have given birth. This figure rises from 1 percent among girls 14-15years old to almost 50 percent among girls 20-22-years old. African females are much more likely to have given birth than other population groups. Only 4 percent of boys said they have fathered a child (i.e., the boy knows he impregnated a girl and the pregnancy resulted in a birth). While 8 percent of rural African and 5 percent of urban African respondents said they have fathered a child, no White, Asian, or Coloured respondent reported fathering a child.

Among girls who have given birth at the time of the study, 18 is the average age at their first child's birth. Males are slightly older: Of the 63 boys who said they have fathered a child (all Africans), the average age is 20 at the time of their first child's birth. 
Table 27 Percentage of pregnancy and birth $(n=3,097)$

\begin{tabular}{lcc|cc}
\hline & $\begin{array}{c}\text { Ever been pregnant/ } \\
\text { made girl pregnant } \\
\text { Female } \\
\%\end{array}$ & $\begin{array}{c}\text { Male } \\
\%\end{array}$ & $\begin{array}{c}\text { Gave birth or fathered a child } \\
\text { Female } \\
\%\end{array}$ & $\begin{array}{c}\text { Male } \\
\%\end{array}$ \\
\hline Population group & & & & 8 \\
$\quad$ African rural & 30 & 9 & 23 & 5 \\
$\quad$ African urban & 27 & 5 & 26 & 0 \\
Coloured & 10 & 9 & 10 & 0 \\
Asian & 7 & 2 & 5 & 0 \\
White & 2 & 1 & 2 & $<1$ \\
Age & & & & 2 \\
$14-15$ & 2 & 1 & 1 & 15 \\
$16-19$ & 22 & 3 & 20 & 4 \\
$20-22$ & 49 & 15 & 45 &
\end{tabular}

\begin{abstract}
Abortion
The gap between pregnancies and births is due to both spontaneous losses of pregnancy and induced abortion; the relative contribution of each is unknown. Table 28 presents results from African female respondents regarding whether their past pregnancies were wanted and if they tried to terminate them (there were too few pregnancies reported by other population groups for meaningful analysis). Nearly three-quarters of this group said they have had an unwanted pregnancy. Among the 14-15 year-old girls who have ever been pregnant, all said they had an unwanted pregnancy.

Although the majority of pregnancies were unwanted, only 2 percent of the girls reported they had ever tried to end the pregnancy. Since 89 percent of the pregnancies actually resulted in childbirth (Table 27), 9 percent remain unaccounted for. Many of these pregnancies may have ended with a spontaneous miscarriage. However, it is also likely that there is some underreporting of abortion since it was only recently legalized in South Africa and is still mainly accessible to adolescents only through traditional abortionists.
\end{abstract}


Table 28 Percentage of female African respondents who had an unwanted pregnancy $(n=391)$

\begin{tabular}{lcc}
\hline & $\begin{array}{c}\text { Ever had an unwanted } \\
\text { pregnancy \% }\end{array}$ & $\begin{array}{c}\text { Ever tried to end a } \\
\text { pregnancy \% }\end{array}$ \\
\hline $\begin{array}{l}\text { Population group } \\
\text { Rural }\end{array}$ & 69 & 1 \\
Urban & 74 & 2 \\
Age & & \\
$14-15$ & 100 & 0 \\
$16-19$ & 71 & 3 \\
$20-22$ & 72 & 1 \\
All & 72 & 2
\end{tabular}

\section{Antenatal care and assistance during delivery}

Because of the elevated risks among adolescents of pregnancy and delivery complications--due to their physiology, lack of knowledge, and in some cases lack of social support--antenatal services provide a crucial opportunity to provide adolescents with health and maternity care and information as well as counseling and testing for HIV and other STDs. Table 29 presents information regarding antenatal care and assistance for the most recent pregnancy among female respondents $(n=366)$. Nearly all (96 percent) of these respondents said they received antenatal care during the pregnancy of their last-born child. Women in the rural areas are slightly more likely to receive antenatal care (99 percent compared to 95 percent of urban), perhaps because adolescent pregnancies are more accepted in rural areas and pregnant girls are encouraged to attend antenatal services. However, nearly all births ( 98 percent) in urban areas took place in medical facilities and were attended by a medical practitioner (97 percent), while in rural areas 90 percent took place in a hospital/clinic and 87 percent were attended by a medical practitioner. 
Table 29 Distribution of women receiving antenatal care and assistance at delivery during pregnancy and birth of last born child $(n=366)$

\begin{tabular}{lccc}
\hline & $\begin{array}{c}\text { Received } \\
\text { antenatal care } \\
\%\end{array}$ & $\begin{array}{c}\text { Birth took place in } \\
\text { medical institution } \\
\%\end{array}$ & $\begin{array}{c}\text { Delivery attended by } \\
\text { medical practitioner } \\
\%\end{array}$ \\
\hline $\begin{array}{l}\text { Population group } \\
\text { Rural African }\end{array}$ & 99 & & \\
Urban African & 95 & 90 & 87 \\
Age & & 98 & 97 \\
$14-15$ & -1 & -1 & --1 \\
$16-19$ & 96 & 97 & 97 \\
$20-22$ & 95 & 95 & 93 \\
All & 96 & 96 & \\
$\quad$ 1Based on $\mathrm{n}=10$ & & &
\end{tabular}

\section{Education and work experience}

\section{Current schooling and work}

As noted in the description of the characteristics of respondents, ${ }^{10}$ the majority of respondents (72 percent) are currently enrolled in school. A fuller description of the study participants' school and work experience is provided here. As can be seen in Table 30, 10 percent of the respondents said they are currently working. Work refers to any kind of work activity for which they earned money. This includes paid as well as self-employment. More men than women are currently employed (13 and 8 percent, respectively). A large difference exists between the proportion of White adolescents currently working and those of the other population groups. Among White respondents, 46 percent have current employment compared to only 14 percent for both Asian and Coloured respondents and only 7 percent of Africans. As expected, the proportion of respondents currently employed increases with age. Nearly half (47 percent) of the students who are currently working also attend school.

\footnotetext{
${ }^{10}$ Section II.2.
} 
Table 30 Current schooling and work experience $(n=3,097)$

\begin{tabular}{|c|c|c|c|c|}
\hline & $\begin{array}{c}\text { Currently in } \\
\text { school and not } \\
\text { working } \\
\%\end{array}$ & $\begin{array}{c}\text { Currently in } \\
\text { school and } \\
\text { working } \\
\%\end{array}$ & $\begin{array}{c}\text { Currently } \\
\text { working and not } \\
\text { in school } \\
\%\end{array}$ & $\begin{array}{c}\text { Currently not } \\
\text { in school or } \\
\text { working } \\
\% \\
\end{array}$ \\
\hline \multicolumn{5}{|l|}{ Sex } \\
\hline Male & 70 & 7 & 7 & 17 \\
\hline Female & 65 & 3 & 4 & 27 \\
\hline \multicolumn{5}{|l|}{$\begin{array}{l}\text { Population } \\
\text { group }\end{array}$} \\
\hline African rural & 68 & 4 & 5 & 24 \\
\hline African urban & 69 & 2 & 4 & 25 \\
\hline White & 48 & 36 & 10 & 6 \\
\hline Coloured & 66 & 12 & 2 & 20 \\
\hline Asian & 71 & 4 & 10 & 15 \\
\hline \multicolumn{5}{|l|}{ Age } \\
\hline $14-15$ & 92 & 3 & $<1$ & 5 \\
\hline $16-19$ & 70 & 5 & 4 & 20 \\
\hline $20-22$ & 37 & 6 & 13 & 45 \\
\hline All & 67 & 5 & 5 & 22 \\
\hline
\end{tabular}

Nearly a quarter (22 percent) of the respondents stated they are neither currently attending school nor working. It should be noted that many of these might be engaged in some kind of unpaid work for their families. More females than males reported not attending school or working (27 percent and 17 percent, respectively). The proportion of respondents who are neither in school nor working increases with age (5 percent of 14-15-year-olds to 45 percent of 20-22-year-olds). This is due to decreased enrollment in school at older ages coupled with the high unemployment in the region. One quarter of African respondents are neither working nor attending school; among other population groups, the comparable figures are 20 percent for Coloureds, 15 percent for Asians, and 6 percent for White respondents.

\section{Work patterns}

Adolescents were asked about their work experiences in general, as well as specific questions about work done in the past 12 months. One quarter of all respondents said they currently do or in the past had done some kind of work for which they are/were paid. Seventeen percent had worked in the 12 months prior to the interviews and 10 percent are currently employed at the time of the interview.

Of those respondents who had ever worked, the average age at which they first started working was 17 years (Table 31). Of these, urban respondents who had ever worked started working at a younger age than their rural counterparts. Over a quarter ( 28 percent) of the respondents who have ever worked started before age 16. More males than females started working before age 16 . Nearly 
half (47 percent) of the White respondents who have ever worked started before age 16, followed by Asian (38 percent), Coloured (29 percent), and urban Africans (19 percent) respondents. Only a small proportion of rural Africans had worked before age 16.

We looked at current work experience of the youngest respondents to assess the nature of the work done by those under 16 . Of the respondents younger than 16,10 percent said they have done some kind of work for which they were paid, 6 percent said they have worked within the past 12 months, and 4 percent said they are currently working. These 14- and 15-year-olds work on average 13 hours per week and receive an average of 106 Rand per week (data not presented in table).

\begin{tabular}{lcc} 
Table 31 & $\begin{array}{c}\text { Age at first paid job among respondents who } \\
\text { ever worked (n= 772) }\end{array}$ \\
\hline & $\begin{array}{c}\text { Age at first } \\
\text { paid job } \\
\text { Mean }\end{array}$ & $\begin{array}{c}\text { First paid job } \\
\text { before age 16 }\end{array}$ \\
\hline & & $\%$ \\
\hline Sex & 17 & 30 \\
Male & 17 & 25 \\
Female & & \\
Population group & 19 & 9 \\
African rural & 17 & 19 \\
African urban & 16 & 29 \\
Coloured & 16 & 38 \\
Asian & 16 & 47 \\
White & $\mathbf{1 7}$ & $\mathbf{2 8}$ \\
All &
\end{tabular}

\section{Time spent at work}

Among all respondents who had worked within the 12 months prior to the interviews, nearly half (47 percent) said it is a full time job (over 32 hours a week) (see Table 32). Among working White and Coloured adolescents (only 16 Coloured respondents reported working full time) this figure is lower, at about one third. Full time jobs are more common in the rural areas; 76 percent of working African adolescents in the rural areas have a full time job compared to 30 percent in the urban areas.

The adolescents who had a job at the time of the interview or had done work in the prior 12 months spend/spent on average 30 hours per week on that job; out-of-school employed youth reported working an average of 39 hours per week while employed in-school youth reported working on average 20 hours per week. White adolescents spend much less time on the job each week (21 hours on average) than other employed adolescents. Rural adolescents are more likely than urban adolescents to be working at a full time job, and of those working, rural adolescents work more hours per week than those in the urban areas do. Females work on average four hours more per week than males. 


\section{Hgrizons}

\section{Earnings and spending}

The average salary earned by adolescents working in the previous 12 months is 239 Rand per week (Table 32). Boys earn around 50 Rand more per week than girls. Africans earn the least (211 Rand per week), while Whites, who spend the least number of hours per week working, earn the most (296 Rand per week). Africans in rural areas, who work the greatest number of hours per week, have more weekly income than the urban African youth with jobs but the same or less income than youth from other population groups. Weekly earnings increase with age, as this is correlated with hours spent on the job.

Similar differences are demonstrated when looking at hourly wages made by working adolescents. While the median wage for girls is 5.8 Rand per hour, the median hourly wage for boys is 8.1 Rand. When comparing the different population groups, White adolescents earn twice as much as any other group. Older adolescents (20-22 years old) earn 8.6 Rand per hour. The median hourly wage of 14-15-year-old adolescents, 7.4 Rand, is higher than median wages of the 16-19-year-old adolescents, 6.3 Rand. This seems to be due to a few among the 42, in the youngest group, who had worked in the past 12 months making a relatively high hourly wage by doing such jobs as DJ-ing during the weekend.

When asked how they spend most of their earnings, adolescents most frequently answered that they use the money for personal entertainment (34 percent), clothes ( 22 percent), food for the family (14 percent) or him/herself ( 8 percent), or savings ( 8 percent). Some give their earnings to their parents (5 percent) and a few use it for education (1 percent). 
Table 32 Number of hours worked per week, weekly earning (Rand) and hourly wages among adolescents working in the last 12 months

\begin{tabular}{lcccc}
\hline & $\begin{array}{c}\text { Has had fulltime } \\
\text { job } \mathbf{( = 3 2} \text { hrs) }\end{array}$ & $\begin{array}{c}\text { Hours worked per } \\
\text { week }\end{array}$ & $\begin{array}{c}\text { Earnings per } \\
\text { week }\end{array}$ & $\begin{array}{c}\text { Rand earned } \\
\text { per hour }\end{array}$ \\
& $\%$ & Mean & Mean & Median $^{*}$ \\
\hline Sex & & & & \\
Male $(n=304)$ & 44 & 28 & 261 & 8.1 \\
Female $(n=225)$ & 52 & 32 & 209 & 5.8 \\
Population group & & & & \\
African rural $(n=91)$ & 76 & 39 & 235 & 4.0 \\
African urban $(n=176)$ & 39 & 30 & 199 & 5.4 \\
Coloured $(n=16)$ & 38 & 29 & 231 & 6.4 \\
Asian $(n=124)$ & 52 & 33 & 242 & 6.9 \\
White $(n=122)$ & 33 & 21 & 294 & 12.7 \\
Age & & & & \\
14-15 $(n=42)$ & 17 & 13 & 106 & 7.4 \\
$16-19(n=275)$ & 46 & 29 & 202 & 6.3 \\
$20-22(n=211)$ & 56 & 35 & 313 & 8.6 \\
All & 47 & 30 & 239 & 6.9
\end{tabular}

* The median hourly wage is presented rather than the mean hourly wage, which is affected by some extreme values reported as monthly earnings.

\section{Schooling experience}

Educational opportunities for adolescents means both staying in school through matriculation, presumably acquiring the required sets of skills, as well as being in the appropriate grade for one's age which shows that youth are developing apace with the curriculum. Thirteen percent of respondents matriculated from school; 5 percent continued with post-secondary education. Another 20 percent left without matriculating. It is possible that some of these respondents may return to school; however, more than 70 percent of school leavers were 18 or older and may consider themselves beyond secondary school age. Table 33 presents the most common reasons cited for interrupting schooling among those who left school without matriculating. The reason most frequently cited by males is that the student or family could not afford the required school fees. The need to work is also an important reason for males. The main reason females drop out is pregnancy; however, high school fees are also a major obstacle to staying in school for females. Other reasons often mentioned by both males and females are illness and lack of interest in school. 
Table 33 Most important reasons for dropping out $(n=622)$

\begin{tabular}{lcc}
\hline & $\begin{array}{c}\text { Male } \\
\%\end{array}$ & $\begin{array}{c}\text { Female } \\
\%\end{array}$ \\
\hline Could not pay school fees & 31 & 30 \\
Pregnant/had a baby & 3 & 39 \\
Needed to work & 22 & 2 \\
Sick & 8 & 5 \\
No interest & 8 & 6
\end{tabular}

The high percentage of girls leaving school because of pregnancy is of central interest to this study. Table 34 presents more detailed data about school leaving as a result of pregnancy. As noted above, 24 percent of female study participants have been pregnant one or more times, and 5 percent of male respondents have made a girl pregnant. Of the girls who have been pregnant, nearly 80 percent were in school at the time. Among boys who have made a girl pregnant, nearly half were in school when this occurred. Of those girls who were in school at the time of the pregnancy, threequarters left school as a result. Among those who left school, 41 percent resumed school after the birth of their child. For those who did not resume their education, the main reason for most is that they had to take care of their new baby ( 82 percent); in the majority of cases (53 percent) the mother is the primary caregiver of the child. Seven percent said the main reason that they did not return is that they cannot afford the school fees, and for some others the family does not allow it (data not presented in table). Among boys, 54 percent of those who were in school when their partner became pregnant left school as a result, and only 22 percent of boys who leave return to school at some time after the birth of the baby (not in table).

Table 34 Left school due to pregnancy

\begin{tabular}{|c|c|c|c|c|}
\hline & \multicolumn{2}{|c|}{$\begin{array}{c}\text { Was in school when first } \\
\text { pregnant/making girl pregnant }\end{array}$} & \multicolumn{2}{|c|}{$\begin{array}{l}\text { Ever left school due to } \\
\text { pregnancy }\end{array}$} \\
\hline & $\begin{array}{c}\text { Male } \\
(n=73) \\
\%\end{array}$ & $\begin{array}{c}\text { Female } \\
(n=411) \\
\%\end{array}$ & $\begin{array}{c}\text { Male } \\
(n=35) \\
\%\end{array}$ & $\begin{array}{c}\text { Female } \\
(\mathrm{n}=326) \\
\%\end{array}$ \\
\hline \multicolumn{5}{|l|}{ Population group } \\
\hline African rural & 39 & 75 & 64 & 73 \\
\hline African urban & 60 & 83 & 48 & 77 \\
\hline Coloured & -- & -- & -- & -- \\
\hline Asian & -- & 47 & -- & -- \\
\hline White & -- & -- & -- & -- \\
\hline \multicolumn{5}{|l|}{ Age } \\
\hline $14-15$ & -- & -- & -- & -- \\
\hline $16-19$ & 52 & 85 & 36 & 78 \\
\hline $20-22$ & 48 & 73 & 58 & 69 \\
\hline All & 49 & 79 & 54 & 75 \\
\hline
\end{tabular}


The full educational history of respondents was recorded in a calendar format. Each respondent was asked to state the grade he/she was attended at each age, starting from 4 through 22 . In the calendar, all full years of education are noted, as well as repeated grades and full and partial years of school absence. Reason for any interruption was also recorded. The profile of school attendance and progress as revealed through the educational history indicate the discrepancies in schooling opportunities and may suggest points of connection to work, childbearing, and sexual health and decision-making.

Among these, a high proportion of African students are well behind the expected grade for their age. For example, students in South African schools are expected to pass their $13^{\text {th }}$ birthday while in Grade 8. Approximately 90 percent of non-African students went through Grade 8 at age 13 or younger. However, only 30 percent of African rural youth and 42 percent of African urban youth attended Grade 8 at the expected age. Almost one third of African students were 15 or older while enrolled in Grade 8. A number of factors contribute to this enrollment pattern, including late entry into primary school and much higher frequency of repeated grades among African students. Primary school in South Africa begins at age six. Among the non-African population groups, more than 90 percent were enrolled at this age. However, only 13 percent of African rural youth and 24 percent of African urban youth enrolled in primary school by age six. Moreover, more than one half of African respondents had repeated at least one grade in primary or secondary school, compared with 22 percent of Coloured, 7 percent of Asians, and 11 percent of Whites.

In addition to age at first attendance in primary school, grade repetition, and temporary dropout (described earlier) also shape the pace and progress of students through school. Grade repetition features prominently among South African students, especially in the African segment of the population. Sixty percent of Africans in urban areas repeat at least one grade during primary or secondary schooling, as do about 56 percent of Africans in rural settings. This figure drops for the other groups: 22 percent of Coloured, 7 percent of Asians, and 11 percent of Whites repeat a grade at some point in their schooling. The estimate of grade repetition does not vary greatly between sexes within population group, with the exception of urban Africans. In this group, 69 percent of boys reported that they repeated at least one grade compared to 53 percent of the girls.

The picture of educational opportunities in South Africa is both promising and disappointing. The vast majority of children attend school, and most eventually finish primary school. The number of young mothers returning to school is also encouraging, especially in light of high levels of early childbearing. However, completing secondary education proves to be too daunting a challenge for some, and the difficulties in timely progression through school may adversely affect many adolescents' subsequent opportunities. 


\section{Hgrizons}

\section{Conclusions}

In these few pages, we have provided a brief and selected review of the sexual health and wellbeing, education, and work of a sample of South African youth as they move toward adulthood and adult responsibilities. The information presented here certainly generates many more questions than answers, and space does not allow adequate exploration of the complex relationships suggested in this last section. However, the data available from this project, in combination with the second wave of findings, advance our understanding of adolescent lives and the risks and opportunities youth must navigate to a broader and more comprehensive understanding. 


\section{References}

Barber, Brian K. 1997. "Adolescent Socialization in Context: the Role of Connection, Regulation, and Autonomy in the Family." Journal of Adolescent Research 12(1): 5-11.

Blanc, Ann K. and Ann A. Way. 1998. "Sexual behavior, contraceptive knowledge and use." Studies in Family Planning 29(2): 106-116.

Bongaarts, John and Barney Cohen. 1998. "Introduction and overview." Studies in Family Planning 29(2): 99-105.

Brooks-Gunn J., G.J. Duncan, P.K. Klebanov, and N. Sealand. 1993. "Do Communities Influence Child and Adolescent Development?” American Journal of Sociology 99(2): 353-395.

Caldwell, John C. et al. 1998. "The construction of adolescence in a changing world." Studies in Family Planning 29(2): 137-153.

Casterline, John B., ed. 1985. The Collection and Analysis of Community Data. Voorburgh, Netherlands: International Statistical Institute.

Central Statistical Service. 1997. Census '96: Preliminary Estimates of the Size of the Population of South Africa. Pretoria: Central Statistics.

Cohen, Deborah, et al. 2000. “'Broken Windows' and the Risk of Gonorrhea." American Journal of Public Health 90(2): 230-236.

Fortenberry, J. Dennis, Frances M. Costa, Richard Jessor, and John E. Donovan. 1997. "Contraceptive Behavior and Adolescent Lifestyles: A Structural Modeling Approach." Journal of Research on Adolescence 7(3): 307-329.

Jessor, Richard, John E. Donovan, and Frances M. Costa. 1994. Beyond Adolescence: Problem Behavior and Young Adult Development. Cambridge: Cambridge University Press.

Jessor, Richard, Mark S. Turbin, and Frances M. Costa. 1998a. "Risk and Protection in Successful Outcomes among Disadvantaged Adolescents." Applied Developmental Studies 2(4) 4: 194208.

1998b. "Protective Factors in Adolescent Health Behavior." Social Science and Medicine 75(3): 788-800.

Jewkes, Rachel, et al. 1999. "He must give me money, he mustn't beat me”: Violence against women in three South African provinces. Pretoria: CERSA (Women's Health), South African Medical Research Council. 


\section{H rizons}

Kaufman, Carol E. 1997. "Reproductive control in South Africa." Policy Research Division, Working Paper No. 97. New York: Population Council.

Kirby, Douglas. 1999. “Antecedents of Adolescent Sexual Risk-taking, Pregnancy and Childbearing: Implications for Research and Programmes.” Draft paper.

Kirby, Douglas. 1997. No Easy Answers: Research Findings On Programme To Reduce Teen Pregnancy. Washington, DC: The National Campaign to Prevent Teen Pregnancy Task Force on Effective Programmes and Research.

Lurie, Mark, et al. 1997. "Circular migration and sexual networking in rural KwaZulu/Natal: Implications for the spread of HIV and other sexually transmitted diseases." Health Transition Review 7 (Supplement 3): 17-27.

Macintyre, Kate et al. 2000. Assessment Of Life Skills Programmes: A Study Of Secondary Schools In Durban Metro And Mtunzini Magisterial District. Durban: School of Development Studies, University of Natal, Durban.

Markham, Jane. 1998. Evaluation Report: Teacher Training Programme. Unpublished mimeo on life skills teachers' training in KwaZulu Natal province, South Africa.

May, J. and P. Gayadeen. 1999. An Overview of the KwaZulu-Natal Income and Expenditure Survey - 1999. DRA/Policy \& Praxis report prepared for the KwaZulu-Natal Department of Economic Affairs \& Tourism and the Ithala Development Bank.

Mazur, Robert E. 1995. Population Structure, Fertility and Childhood Mortality in South Africa: Lessons to be Learned from Analysis of the Poverty Survey. Tygerburg, South Africa: Centre for Epidemiological Research in Southern Africa, South African Medical Research Council.

McCauley, Ann. 2001. Personal communication.

Mensch, Barbara, Judith Bruce, and Margaret E. Greene. 1998. The uncharted passage: girls' adolescence in the developing world. New York: Population Council.

Preston-Whyte, Eleanor. 1990. "Qualitative perspectives on fertility trends among African teenagers," in South Africa's Demographic Future, ed. W.O. Mostert and J.M. Lotter. Pretoria: Human Sciences Research Council.

Resnick, Michael D. et al. 1997. "Protecting Adolescents from Harm: Findings form the National Longitudinal Study on Adolescent Health." Journal of the American Medical Association 278, (10): 823-832

Rickard, Carmel. 1999. "Christians must spare the rod says High Court—Schools fail in their quest to have corporal punishment legalized." Sunday Times, Johannesburg, August 8. 
South Africa Department of Health. 1999. National Annual Survey of Antenatal Clinics 1998. Pretoria.

South Africa Department of Health and South Africa Department of Education, 1997/98. Life Skills and HIV/AIDS Education Programme: Project Report.

Stavrou, S.E. and C.E. Kaufman. 2000. “ 'Bus fare please': The economics of sex, gifts and violence among adolescents in Durban, South Africa." Paper presented at the annual meeting of the Population Association of America, Los Angeles, CA, March 23-25.

Travers, Graham. 1998. "Corporal punishment of children: Developments in South Africa," letter of 12/19/98 to Parents and Teachers Against Violence in Education (PTAVE). http://nospank.org/travers.htm.

Varga, Christine. 1997. "Sexual decision-making and negotiation in the midst of AIDS: Youth in KwaZulu/Natal, South Africa." Health Transition Review 7(Supplement 2): 13-41.

. 1999. "South African young people's sexual dynamics: Implications for behavioural responses to HIV/AIDS," in Resistances to Behavioural Change to Reduce HIV/AIDS in Predominantly Heterosexual Epidemics in Third World Countries, ed. J.C. Caldwell et al. Canberra: Health Transition Centre, National Center for Epidemiology and Population Health, Australia National University.

Whiteside, A. 1999. "SA's 1998 survey results show no let-up," AIDS Analysis Africa 10(1).

Wood, Katharine and Rachel Jewkes. 1997. "Violence, rape, and sexual coercion: Everyday love in a South African township." Gender and Development. 5(2):41-46.

Zabin, Laurie and Karungari Kiragu. 1998. "Health consequences of adolescent sexuality and fertility behavior in sub-Saharan Africa." Studies in Family Planning 29(2): 210-232. 